\title{
Don't be cruel (anymore): a look at the animal cruelty regimes of the united states and brazil with a call for a new animal welfare agency
}

\section{Não seja mais cruel: um olhar sobre métodos cruéis contra animais dos Estados Unidos e do Brasil e uma demanda por uma nova agência de bem-estar animal}

\author{
David N. Cassuto* \\ Cayleigh Eckhardt ${ }^{* *}$
}

No man who has passed a month in the death cells believes in cages for beasts.

-Ezra Pound (from the Pisan Cantos)

\begin{abstract}
In the United States and around the world, animals exploited for hu-man use suffer cruel and needless harm. The group bearing the brunt of this exploitation-agricultural animals - is routinely exempted from the largely ineffective and rarely enforced animal welfare and anti-cruelty regulations that exist today. This Article offers a comparative analysis of the agricultural animal welfare regimes of two countries with globally significant presence in the agriculture industry: the United States and Brazil. Even though the two countries approach agricultural animal welfare differently, they arrive at the same outcome: institutionalized indifference to animal suffering. To remedy the current regulatory structure, this Article proposes the creation of an independent federal agency-The Animal Welfare Agency ("AWA") - to regulate the safety and welfare of all animals, including those used in agriculture. The AWA could significantly reduce systemic animal cruelty in both the United States and Brazil and repre sent an important step toward inserting morality and ethics into our relationships with animals.
\end{abstract}

Keywords: Animal Welfare Agency; agriculture animal cruelty regime; 
* Professor of Law, Pace Law School, Director of Brazil-American Institute for Law \& Environment (BAILE), Visiting Professor of Law, Federal University of Bahia, Brazil (UFBA), Class of 1946 Distinguished Visiting Professor of Environmental Studies, Williams College. J.D., University of California Berkeley, $\mathrm{PhD}$, Indiana University, B.A., Wesleyan University. The author is much indebted to Rafael Wolff for his expertise and for his generosity with it. In addition, Drew Levinson provided invaluable and excellent research assistance.

** Research Assistant to Professor David Cassuto and 2015 graduate of Pace University School of Law. I would like to thank Professor David Cassuto for his guidance and support over the past three years and for always pushing me to ask the tough questions and think creatively to find the answers. I would also like to thank Rafael Wolff, Federal Judge in Brazil and S.J.D. Candidate at Pace University School of Law, for being a constant resource and providing invaluable expertise and knowledge of Brazilian law.

\section{Resumo:}

Nos Estados Unidos e ao redor do mundo, animais explorados para uso humano sofrem tratamentos cruéis e desnecessários. O grupo que carrega o peso dessa exploração - os animais da agricultura - é rotineiramente isento das regras de bem-estar animal e anti-crueldade, sendo essas regaras atualmente ineficazes e raramente aplicadas. Este artigo oferece uma análise comparativa dos regimes de bem-estar de animais agrícolas de dois países com presença globalmente significativa na indústria agrícola: os Estados Unidos e o Brasil. Mesmo que os dois países se aproximem do bem-estar animal agrícola, eles chegam ao mesmo resultado: indiferença institucionalizada ao sofrimento animal. Para remediar a atual estrutura regulatória, este Artigo propõe a criação de uma agência federal independente - a Agência de Bem-Estar Animal ("AWA") - para regular a segurança e o bem-estar de todos os animais, incluindo aqueles usados na agricultura. O AWA poderia reduzir significativamente a crueldade sistêmica contra animais nos Estados Unidos e no Brasil e representar um passo importante para inserir a moralidade e a ética em nossos relacionamentos com os animais.

Palavras-chave: Agencia de Bem Estar Animal; métodos cruéis em animais rurais. 


\section{INTRODUCTION}

Cruelty to animals is commonly defined as a malicious or criminally negligent act that causes an animal to suffer pain or death. ${ }^{1}$ Historically, animal anti-cruelty statutes in the United States were enacted because, "[I]f left to its own devices, society would exploit animals without regard to moral or ethical consideration." "2 Judging by the vast and increasing number of exploited animals, these statutes have had little of the desired impact. ${ }^{3}$ Over 9.1 billion land animals are killed in the United States for food each year. ${ }^{4}$ For most of them, their lives (and deaths) occur outside of the law's protection, with little thought given to their well-being. ${ }^{5}$ In fact, many states specifically exempt farm animals from anti-cruelty statutes. ${ }^{6}$ This practice-excluding agricultural animals from anti-cruelty protections-is not unique to the United States. Rather, it is the norm globally, and the resulting animal suffering reaches an almost incomprehensible scale. ${ }^{7}$

In an effort to understand the rationale behind excluding agricultural animals from legal protections, this Article offers a comparative analysis of

${ }^{1}$ Cruelty, Black's Law Dictionary (10th ed. 2014). States do vary in their codified definition of cruelty, but usually incorporate the concept of unnecessary, needless, or unjustified suffering into their definitions. See MASs. GEN. Laws ch. 272, § 77 (2015) (illegal to "inflict[] unnecessary cruelty upon [an animal], or unnecessarily fail[] to provide it with proper food, drink, shelter, sanitary environment, or protection from the weather"); Miss. CODE. ANN. § 97-41-1 (2015) (misdemeanor to "unjustifiably injure ... or needlessly mutilate[] or kill[], any living creature"); N.Y. AGRIC. \& MKTS. LAW § 353 (McKinney 2015) (misdemeanor to "unjustifiably injure[], maim[], mutilate[] or kill[] any animal").

2 David J. Wolfson, Beyond the Law: Agribusiness and the Systemic Abuse of Animals Raised for Food or Food Production, 2 AnIMAL L. 123, 148 (1996).

${ }^{3}$ See Farm Animal Statistics: Slaughter Totals, HumAnE SOC'Y OF THE U.S., http://www.humane society.org/news/resources/research/stats_slaughter_totals.html [http://perma.cc/M9XR-ZT2M] (last updated June 25, 2015).

${ }^{4}$ Id.

${ }^{5}$ See Gaverick Matheny \& Cheryl Leahy, Farm-Animal Welfare, Legislation, and Trade, 70 LAW \& CONTEMP. PROBS. 325, 326 (2007) (noting that excluding water animals from these figures is more a function of societal practice (and prejudice) than an acknowledgment that their plight is any less dire, and that aquaculture as well as open water fishing are responsible for billions more deaths and unquantifiable suffering); David E. Solan, Et Tu Lisa Jackson? An Economic Case for Why the EPA's Sweeping Environmental Regulatory Agenda Hurts Animal Welfare on Factory Farms, 8 J. ANimal \& NAT. ResourCE L. 27, 34-36 (2012).

${ }^{6}$ David J. Wolfson \& Mariann Sullivan, Foxes in the Henhouse: Animals, Agribusiness and the Law: A Modern American Fable, in ANimal Rights: CuRRent Debates and New DirecTIONs 205, 207 (Cass R. Sunstein \& Martha C. Nussbaum eds., 2004).

7 Stephanie J. Engelsman, "Word Leader" - At What Price? A Look at Lagging American Animal Protection Law, 22 PaCe EnvTL. L. Rev. 329, 332 (2005). 
two countries-Brazil and the United States. We selected these countries because their respective animal agricultural regimes have global significance and impact, ${ }^{8}$ and because their legal systems are dissimilar in approach but similar in result. Like the United States, Brazil exempts agricultural animals from legal protections afforded to other animals. ${ }^{9}$ However, unlike the United States, Brazil's Constitution explicitly recognizes a fundamental right of humane treatment for animals. ${ }^{10}$ Still, Brazilian agricultural animals remain vulnerable to systemic abuse. ${ }^{11}$ This Article explores why these two countries' varying approaches to animal cruelty arrive at substantially the same end. Profit clearly serves as a driving force in both countries but does not necessarily explain the institutionalized indifference to suffering. One can seek profit while still remaining sensitive to the im-pacts on others. There are many examples of entities that have done well financially while remaining mindful of social responsibilities. ${ }^{12}$

${ }^{8}$ See David N. Cassuto \& Sarah Saville, Hot, Crowded, and Legal: A Look at Industrial Agriculture in the United States and Brazil, 18 AnImal L. 185, 195, 201 (2012). The United States has only five percent of the world's population yet consumes fifteen percent of the world's animals. Id. at 195. It is also the place where industrial agriculture began. Id. at 191. Brazil is one of the world's leading exporters of cattle and chicken and one of the largest live exporters, as well. Id. at 200. "From 1995-2010, Brazil's cattle herd increased 27\%, national beef production increased 38\%, and the county's exports jumped by $731 \%$." Id. at 201 .

9 Id. at 202-03; see Directorate Gen. FOR Health \& Consumer Prot., European COMm'N, ANimal Welfare 1 (2007), http://ec.europa.eu/food/animals/docs/aw_efsa_opinions_ factsheet_farmed03-2007_en.pdf [http://perma.cc/529N-5C7P]; infra notes 146-178 and accompanying text (noting that Brazil's regulations pertaining to animals used in agriculture conform to European Union standards, which are more rigorous than those of the United States). See generally WORLD BANK, WORLD DEVElOPMENT INDICATORS: 2011 (2011), http://siteresources.world bank.org/DATASTATISTICS/Resources/wdi_ebook.pdf [https://perma.cc/7YQY-LYBN] (provid-ing statistical information about world development indicators, showing differences in develop-ment and quality of life around the world).

${ }^{10}$ See Constituição Federal [C.F.] [Constitution] art. 225 (Braz.) (stating that the federal government must "protect the fauna and flora ... [from] practices that endanger their ecological function, cause the extinction of species or subject animals to cruelty") (trans.) (emphasis added).

${ }^{11}$ Tagore Trajano de Almeida Silva, Brazilian Animal Law Overview: Balancing Human and Non-Human Interests, 6 J. ANIMAL L. 81, 86 (2010) (stating that laboratory animals also exist in a form of legal limbo: on the one hand, they have constitutional protections, on the other, the law permits their use and exploitation); see Raul Gallegos, Beagle Brutality Sets Off Brazil, BLoomBERG VIEW (Oct. 31, 2013, 8:18 PM), http://www.bloomberg.com/news/2013-10-31/beaglebrutality-sets-off-brazil-.html [http://perma.cc/N8CK-B97A] (noting that in October 2013, Brazilian animal-rights activists broke into a laboratory and freed 178 beagles to both rescue the animals and communicate their desire to ban laboratory animal testing); Chesney Hearst, Animal Cruelty Debate Continues: Daily, Rio TIMES (Oct. 27, 2013), http://riotimesonline.com/brazil-news/riopolitics/animal-cruelty-debate-continues/\# [http://perma.cc/D3N2-LYDQ].

${ }^{12}$ See, e.g., Brad Tuttle, Chipotle Pulls Pulled Pork from 600 of Its Restaurants, TIME (Jan. 14, 2015), http://time.com/money/3667333/chipotle-pork-carnitas-shortage/ [http://perma.cc/BBL3-AZHN]; Animal Welfare Standards, WHOLE FoODS MKT., http://www.wholefoodsmarket.com/ about-ourproducts/quality-standards/animal-welfare-standards [http://perma.cc/9L7K-X43D]; Whole 
Part I of this Article provides an overview of the regulatory regimes of the two countries with respect to agricultural animals. ${ }^{13}$ Although each has laws mandating "humane treatment," the scope and nature of that term leave much to interpretation. In the United States, for example, the principal federal statute supposedly guaranteeing humane treatment is the Federal Meat Inspection Act ("FMIA"), a law whose very title indicates that (living) animal protection is not the priority. ${ }^{14}$ Brazil's laws are similarly riven with internal contradiction. ${ }^{15}$

Part II explores the countries' across-the-board exemptions for agricultural animals in almost all animal cruelty legislation or regulation. ${ }^{16}$ Part III examines how political pressure from the agricultural industry, consumer demand, and laws aimed at incentivizing the production of animal products rather than maximizing animal welfare have resulted in subsidies (in the United States), favorable regulatory structures (in both countries), and a proliferation of inhumane practices. ${ }^{17}$

Finally, Part IV offers a potential solution to the entrenchment of agricultural practices that fail to adequately account for animal welfare in both the United States and Brazil. ${ }^{18}$ There must be a new regulatory body devoted to the conditions of animals. Specifically, we call for the creation of a federal agency - The Animal Welfare Agency ("AWA") — to regulate animal safety and welfare. ${ }^{19}$ The AWA would assume responsibility for animal welfare from existing regulatory bodies, thereby removing the potential for agency capture and conflict. ${ }^{20}$ The agency would have jurisdiction over all animal welfare. However, because the majority of animals and animal mistreatment occurs in agriculture, the focus here is on agricultural animals. ${ }^{21}$

Foods Begins Animal Welfare Labeling, HOARD's DAIRYMAN (Mar. 30, 2011), http://www.hoards. com/blog_whole_foods [http://perma.cc/X3JZ-6UQR]; Why Did Chipotle Stop Serving Carnitas?, ChipotLE.CoM, http://chipotle.com/carnitas [http://perma.cc/H98Y-BZGJ] (explaining that Chipotle stopped serving carnitas in many restaurants because a supplier violated some of Chipotle's animal welfare standards).

${ }^{13}$ See infra notes $26-178$ and accompanying text.

${ }^{14}$ Federal Meat Inspection Act, 21 U.S.C. $\$ \S 601-695$ (2012); see also Humane Methods of Slaughter Act, 7 U.S.C. $\S \S 1901-1902$ (2012) (regulated by the Department of Agriculture); Animal Welfare Act, 7 U.S.C. $\S \S 2131-2159$; Twenty Eight Hour Law, 49 U.S.C. $\$ 80502$ (2012) (protecting animals during transportation to slaughter); Cassuto \& Saville, supra note 8, at 203.

${ }^{15}$ See Lei No. 9.605, de 12 de Fevereiro de 1998, Diário Oficial Da União [D.O.U.] de 13.2.1998 (Braz.).

\footnotetext{
${ }_{17}^{16}$ See infra notes 179-212 and accompanying text.

${ }_{18}^{17}$ See infra notes 213-264 and accompanying text.

${ }_{18}^{18}$ See infra notes 266-326 and accompanying text.

${ }^{19}$ See infra notes 269-326 and accompanying text.

${ }^{20}$ See infra notes 273-285, 298-315 and accompanying text.

${ }^{21}$ See infra notes 286-294, 316-317 and accompanying text.
} 
We further demonstrate how an AWA could be successfully established in Brazil and the United States. 22

The Article concludes with a brief discussion of the potential improvements in animal welfare, worker and food safety, and environmental protection offered by our proposed Agency. ${ }^{23}$ Realpolitik and powerful economic interests guarantee that this proposal will face a difficult road, and require a great deal of political courage and will. However, the degree of difficulty is dwarfed by the necessity for action. Billions of animals die in horrible agony every year in the United States and Brazil. $^{24}$ Considering the economic and political power the agricultural industry possesses in both countries, a suggestion to ban industrialized agricultural production is not workable. ${ }^{25}$ The purpose of this Article is to offer ideas for improving ani-mal welfare based on current realities. The present regulatory structure is irremediably flawed; it is time for a new start.

\section{LEgAL TREATMENT OF ANIMALS IN THE AgRICULTURAL INDUSTRY}

Both Brazil and the United States recognize the need for laws protecting animals from cruelty. ${ }^{26}$ These laws vary in scope from region to re-gion. ${ }^{27}$ However, neither country provides adequate protection for animals within the agricultural industry. Because agricultural animals are viewed as food, and food is necessary for life, the suffering of animals raised for food has traditionally been viewed as unavoidable. ${ }^{28}$

This notion of necessity contains an embedded and ironic double standard. Anti-cruelty laws, even applied to agricultural animals, usually outlaw the infliction of "unnecessary" suffering. ${ }^{29}$ Necessity, as a legal concept, is typically defined from the perspective of the potential victim; for

${ }^{22}$ See infra notes 269-326 and accompanying text.

${ }^{23}$ See infra notes 318-326 and accompanying text.

${ }^{24}$ See supra notes 4-7 and accompanying text (noting that billions of animals suffer and die for food in the United States); infra notes 170-178 and accompanying text (describing how the hundreds of thousands of cattle killed annually for food in Brazil suffer terribly).

${ }^{25}$ See infra notes 213-264 and accompanying text.

${ }^{26}$ See, e.g., CONSTITUIÇão Federal [C.F.] [CONSTItUTION] art. 225 (Braz.); Animal Wel-fare Act, 7 U.S.C. $\$ \S 2131-2159$ (2012).

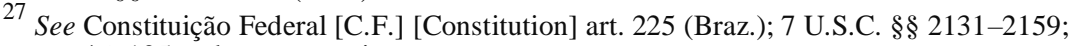
infra notes 46-105 and accompanying text.

${ }^{28}$ Wolfson, supra note 2, at 148. See generally David N. Cassuto, Meat Animals, Humane Standards and Other Legal Fictions, LAw, CUlTURE \& HUMAN. (forthcoming), http://digital commons.pace.edu/cgi/viewcontent.cgi?article=1874\&context=lawfaculty [perma.cc/LJZ8-83L9] (detailing how supposedly humane federal practices ignore the brutal treatment of "food animals").

29 See Frida Lundmark et al., 'Unnecessary Suffering' as a Concept in Animal Welfare Legislation and Standards, in ThE ETHICs OF CONSUMPTION: THE Citizen, THE MARKET AND THE 
example, one can kill in self-defense when it is necessary to avoid deadly harm to oneself. ${ }^{30}$ In that instance, the victim of an attack can inflict suffering upon her attacker to avoid a potentially worse outcome (her own death). The law recognizes that the death of the attacker is preferable to the death of the victim.

That relationship between potential victim and legal necessity is inverted in the case of animal cruelty. For example, no one would argue that it is necessary for a calf to be castrated in order for that calf to avoid a worse fate. Rather, the business interests of the human owner of the calfthe entity inflicting the suffering-take precedence over the calf's wellbeing and bodily integrity. Thus, because it is more profitable for the calf's owner to remove the calf's testicles (rendering it more docile and therefore more manageable), it becomes justifiable and legally "necessary" to castrate the calf. ${ }^{31}$

There are several discrete but linked ideas within this rationale that diverge from the standard logic of cruelty, necessity, and common sense. First, as mentioned, necessity is judged not from the perspective of the victim but rather that of the instigator of the suffering. ${ }^{32}$ This raises a jurisprudential question: if an animal's suffering is irrelevant to the determination of necessity, can the animal enduring cruelty legitimately be classified as a victim? ${ }^{33}$ This question leads one to then inquire whether legitimate victims can actually exist under animal cruelty statutes. ${ }^{34}$

Second, the idea of necessity in the animal cruelty context revolves around economics. ${ }^{35}$ For instance, debeaking chickens or docking the tails of pigs or dairy cattle makes it easier to confine the animals in very close

${ }^{30}$ See, e.g., LA. STAT. ANN. $§ 14: 20$ (2015) (stating that homicide is justifiable when committed in self-defense); N.Y. Penal LaW $\S 35.15$ (McKinney 2015) (describing that a person may use deadly physical force for self-defense against another that he believes will use deadly force upon him).

${ }^{31}$ Gary Francione, ANimals, Property, AND the LAW 26 (1995) (noting that no anesthesia is used when carrying out the procedure). See generally AM. VETERINARY MED. ASS'N, LITERATURE Review on the Welfare Implications of Castration of Cattle (2014), https://www. avma.org/KB/Resources/LiteratureReviews/Documents/castration-cattle-bgnd.pdf [http://perma. cc/79JT-K85B] (explaining the current lack of use of anesthesia in the castration procedure while advocating for the benefits of using anesthesia to minimize the animal's pain and stress associated with the castration process).

${ }^{32}$ FrANCIONE, supra note 31, at 26.

${ }^{33}$ See generally Luis E. Chiesa, Why Is It a Crime to Stomp on a Goldfish?-Harm, Victimhood and the Structure of Anti-Cruelty Offenses, 78 Miss. L.J. 1 (2008) (arguing that society has decided to criminalize harm to animals primarily out of concern for the well-being of such creatures, not because doing so furthers some other human interest).

${ }^{34}$ See id. at 34 (explaining that though widely misperceived, cruelty laws are in fact meant to protect animal victims).

${ }^{35}$ See Francione, supra note 31, at 26.

Revista Juris Poiesis - Rio de Janeiro. Vol.21-n²5, 2018, pg.211-270 252. ISSN 2448-0517-

Rio de Janeiro, 29 de abril de 2018. 
quarters. ${ }^{36}$ The industry maintains that these procedures, which result in lasting pain and discomfort for the animals, nevertheless increase the yield of animal products. ${ }^{37}$ In the eyes of the law, that economic benefit translates into "necessity."

In no other context with which the authors are familiar does profit determine whether the infliction of suffering is legally necessary. Nonetheless, as animal agriculture has industrialized, economic gain has become ever more determinative of animal welfare. ${ }^{38}$ Furthermore, as has been widely discussed, modern agricultural practices differ significantly from those of small farms of the past, both in the systematization and the sheer scale of the suffering they inflict. ${ }^{39}$ This section provides an overview of the treatment of agricultural animals in the United States and Brazil. ${ }^{40}$

\section{A. Regulation in the United States}

In the United States, the few federal animal protection laws that exist deal primarily with transport and slaughterhouse protocols. ${ }^{41}$ The rest is left to the states. ${ }^{42}$ Unfortunately, most states exempt "common" or "normal"

${ }^{36}$ DAVID FAVRE, ANIMAL LAW: WELFARE, INTERESTS, AND Rights 293 (2008).

37 See generally Gulnaz Shaheen, Factory Farming: A Cruel Practice, 3 AYER 91 (2015) (explaining the cruelty present in farming operations).

38 Michael Pollan, Farmer in Chief, N.Y. Times (Oct. 9, 2008), http://www.nytimes.com/ 2008/10/12/magazine/12policy-t.html?rref=collection\%2Ftimestopic\%2FPollan\%2C\%20Michael \&action $=$ click \& contentCollection $=$ timestopics\&region=stream\&module $=$ stream_unit \&version=la test\&contentPlacement=37\&pgtype=collection. See generally David N. Cassuto, Owning What You Eat: The Discourse of Food, 4 Revista BRASILERIA DE DiREITO ANIMAL 45 (2009) (explaining that industrial agriculture has refashioned animal husbandry into a mechanized process that ignores historic methods of human/nonhuman animal interaction).

39 Elizabeth A. Overcash, Comment, Unwarranted Discrepancies in the Advancement of Animal Law: The Growing Disparity in Protection Between Companion Animals and Agricultural Animals, 90 N.C. L. REV. 837, 875-76 (2012). See generally Joyce D'Silva, Adverse Impact of Industrial Animal Agriculture on the Health and Welfare of Farmed Animals, 1 INTEGRATIVE ZOOLOGY 53 (2006) (explaining how maximizing productivity has been the driving force in the increasingly intensive nature of the farming of animals, and has resulted in serious threats to the health and welfare of the animals involved); Joyce D'SILVA \& PETER STEVEnSOn, Compassion IN WORLD FARMING TR., MODERN BREEDING TECHNOLOGIES AND WELFARE OF FARM ANIMALS (1995), https://www.ciwf.org.uk/media/3816969/modern-breeding-technologies-and-farm-animalwelfare.pdf [http:perma.cc/2UMT-STBR] (discussing how modern methods of breeding are threatening farm animal health and welfare).

${ }^{40}$ See infra notes $41-178$ and accompanying text.

${ }^{41}$ See infra notes 45-73 and accompanying text.

42 See Gary L. Francione, Introduction to Animal Rights: Your Child or the Dog? 56-58 (2000) (explaining the protocols in states including California, Delaware, Kentucky, Maryland, Nebraska, Oregon, and Pennsylvania). 


\section{JURIS POIESIS \\ REVISTA DO CURSO DE DIREITO DA UNIVERSIDADE ESTACIO DE SA}

farming practices from their anti-cruelty statutes. ${ }^{43}$ Consequently, agricultural animals have little or no legal protection from inhumane treatment. $^{44}$

\section{Federal Law}

No federal regulations or statutes "govern the way that [agricultural] animals are treated from the time that they are born or hatched to the time they are sent off to be slaughtered." 45 The few federal laws that do exist focus on the animals' transport, slaughter, or condition immediately prior to slaughter, not on the nature of their pre-transport existence. ${ }^{46}$

The Humane Methods of Slaughter Act ("HMSA") is overseen by the Department of Agriculture ("USDA"). ${ }^{47}$ The statute charges the agency with regulating the kill methods used in federally approved slaughterhouses. ${ }^{48}$ However, the USDA has determined that the HMSA excludes both birds and fish, ${ }^{49}$ even as birds and fish account for roughly ninety-nine percent of farmed animals. ${ }^{50}$ Thus, the few protections offered by the HMSA apply only to the land mammals that comprise the remaining one percent of domestically slaughtered animals. ${ }^{51}$ The HMSA is even further limited be-cause it exempts ritual slaughter. ${ }^{52}$

${ }^{43}$ See Colo. Rev. STAT. § 18-9-201.5 (2015); IDAho Code § 25-3514(5) (2015); 510 IlL. Comp. Stat. 70/13 (2015); Iowa Code $§ 717.2(1)$ (a), (c) (2015); Mont. Code AnN. § 45-8211(4)(b) (2015); NeV. REV. STAT. § 574.200 (2015); see also Wolfson, supra note 2, at 127-32.

${ }^{44}$ See infra notes 45-122 and accompanying text (describing the inadequacy of federal and state laws in protecting agricultural animals).

${ }^{45}$ Cheryl L. Leahy, Large-Scale Farmed Animal Abuse and Neglect: Law and Its Enforcement, 4 J. ANimal L. \& Ethics 63, 75 (2011); see Humane Methods of Slaughter Act, 7 U.S.C. $\S \S 1901-1907$ (2012) (governing animal treatment only as it relates to methods of slaughter); PEW Comm'n on Indus. Farm Animal Prod., Putting Meat on the Table: Industrial Farm Animal Production in America 30 (2008); see also Animal Welfare Act, 7 U.S.C. $\S \S 2131-$ 2159 (only regulating the welfare of animals being used for research, which does not include agricultural animals); Twenty Eight Hour Law, 49 U.S.C. § 80502 (2012) (requiring minimum standards of care for animals during transportation).

${ }^{46}$ See 7 U.S.C. $\S \S 1901-1907,2131-2159 ; 49$ U.S.C. $\S 80502$.

477 U.S.C. $\$ \$ 1901-1902$.

${ }^{48} I d$.

${ }^{49}$ Id.; see also 9 C.F.R. $\S 301.2$ (2015) (defining livestock as "[c]attle, sheep, swine, goat, horse, mule, or other equine").

${ }^{50}$ Matheny \& Leahy, supra note 5, at 326.

${ }^{51}$ Rachel Wechsler, Blood on the Hands of the Federal Government: Affirmative Steps That Promote Animal Cruelty, 4 J. ANIMAL L. \& ETHICs 183, 200-01 (2011).

527 U.S.C. $\$ 1902$ (b) (defining humane slaughter to include "slaughtering in accordance with the ritual requirements of the Jewish faith or any other religious faith that prescribes a method of slaughter whereby the animal suffers loss of consciousness by anemia of the brain caused by the 

arteries with a sharp instrument and han-dling in connection with such slaughtering"). 


\section{JURIS POIESIS

In addition, the regulations designed to reduce suffering during slaughter are largely ineffectual. ${ }^{53}$ For example, though the HMSA requires that animals be rendered senseless prior to their being hoisted, shackled, and cut, many receive inaccurate stun blows. ${ }^{54}$ As a result, these poorly stunned animals are often skinned alive. ${ }^{55}$ Therefore, even the small percentage of animals supposedly protected under the HMSA can still suffer during slaugh-ter. ${ }^{56}$

The second of the two principal federal laws governing the treatment of agricultural animals is the FMIA, which pertains to animals once they reach the slaughterhouse. ${ }^{57}$ The FMIA mandates that these animals be treated humanely only during the slaughter process. ${ }^{58}$ Yet, the FMIA still allows animals who are injured and already suffering to be slaughtered, thus creating a perverse incentive to mistreat animals prior to their arrival (mistreatment is usually less expensive than humane treatment). ${ }^{59}$

In 2012, the United States Supreme Court ruled that Section 599 of the California Penal Code, which was amended to provide more slaughterhouse protections, was preempted by the FMIA. ${ }^{60}$ In finding that the FMIA's animal welfare standards preempted state law, Justice Kagan references "humane" treatment only as it relates to slaughterhouses. ${ }^{61}$ Such a narrow perspective excludes most of the animals' lives and, therefore, much of the cruelty they endure.

A third relevant federal law, Section 80502 of Title 49 of the United States Code, known as the "Twenty-Eight Hour Law," ostensibly provides protection for animals during transport to slaughter. ${ }^{62}$ It requires that livestock transported by a common carrier vehicle for over twenty-eight con-

${ }^{53}$ Leahy, supra note 45 , at $75-76$.

${ }^{54}$ See 7 U.S.C. $§ 1902$ (a); Cassuto, supra note 28, at 4.

${ }^{55}$ Cassuto, supra note 28, at 4 ("[T] he rapidity of the modern industrial kill line ensures that there will inevitably be some inaccurate stun blows. That means that some percentage (even $0.5 \%$ still amounts to thousands of animals) is not properly stunned. Those poorly stunned animals are often skinned alive.").

${ }_{57}^{56}$ See 7 U.S.C. $\$ 1902$ (a); Cassuto, supra note 28 , at 4.

5721 U.S.C. $\$ \S 601-695$ (2012).

${ }^{58}$ Id. The FMIA allows animals who, after arrival at the slaughterhouse, are seriously injured to be butchered and sold for human consumption. Cassuto, supra note 28, at 6 . Therefore, there is "little disincentive for industrial meat producers and their transporters to invest in the animals" wellbeing." Id.

${ }^{59}$ Cassuto, supra note 28, at 6; Matheny \& Leahy, supra note 5, at 327-29, 346 tbl.3.

${ }^{60}$ See 21 U.S.C. § 678; Nat'1 Meat Ass'n v. Harris, 132 S. Ct. 965, 968, 970-71 (2012) (holding that the FMIA explicitly prohibits state-imposed animal handling requirements that are "in addition to, or different than those made under this [Act]").

${ }^{61}$ See Nat'l Meat Ass'n, 132 S. Ct. at 968; Cassuto, supra note 28, at 3-4.

${ }^{62}$ See 49 U.S.C. $\$ 80502$ (2012). 
secutive hours have at least five hours of rest as well as food and water. ${ }^{63}$ This law - which also excludes birds - fails in its application. ${ }^{64}$ Not only do the regulations allow birds to be confined indefinitely, ${ }^{65}$ but the law's very title reveals a marked indifference to all other animals' well-being. If nonavian animals cannot be confined for more than twenty-eight hours, that means that they can be confined for up to twenty-eight hours without food, water, or space to move. ${ }^{66}$ Clearly, a law permitting such treatment has very little to do with actually safeguarding animal welfare. ${ }^{67}$

In addition, as with the HMSA, the Twenty-Eight Hour Law is riddled with exemptions. ${ }^{68}$ For example, "Sheep may be confined an additional eight consecutive hours without being unloaded when the twenty-eight-hour period of confinement ends at night." ${ }^{69}$ Because the owner has a vested interest in the animals reaching market as soon as possible, there is a clear incentive to ignore the animals' comfort in favor of speeding up their transport. Moreover, even putting aside its exemptions, the Twenty-Eight Hour Law is ineffective in practice because it is rarely enforced. ${ }^{70}$ The last known enforcement action dates back to $1960 .^{71}$ Finally, even if the law were properly enforced (or enforced at all), its maximum penalty is $\$ 500$ per shipment. ${ }^{72}$ Offenders could easily absorb such fines as the cost of doing business. 73

\section{State Laws}

State laws offer little more protection than the federal statutes. ${ }^{74}$ While all states in the United States have anti- cruelty laws, agricultural animals remain largely unprotected because they are explicitly exempted from the

${ }^{63}$ Id.; see also Leahy, supra note 45 , at 76.

${ }^{64}$ See 9 C.F.R. § 89.1 (2015) (defining requirements under the Twenty Eight Hour Law; omitting categories for treatment for birds); see also Matheny \& Leahy, supra note 5, at 335.

${ }^{65}$ See 9 C.F.R. $§ 89.1$. Because the regulations do not apply to birds, holding birds for a period longer than twenty-eight hours will not violate the law. See id.

${ }_{67}^{60}$ See generally, 49 U.S.C. $\$ 80502$.

${ }^{67}$ Cassuto, supra note 28 , at 7-8.

${ }^{68}$ See 49 U.S.C. $\$ 80502($ a)(2).

${ }^{69} \mathrm{Id}$.

${ }_{71}^{70}$ See Matheny \& Leahy, supra note 5, at 334-36.

${ }^{71}$ See 49 U.S.C. $\$ 80502$ (a)(2); S. Pac. Transp. Co. v. Comm'r, 75 T.C. 497, 502, 643, 654 (1980) (referencing Twenty Eight Hour Act violations committed in 1960 and 1961); Matheny \& Leahy, supra note 5, at 335; see also Cassuto \& Saville, supra note 8, at 199.

72 See 49 U.S.C. $\$ 80502$ (d) (providing for a civil penalty of "at least $\$ 100$ but not more than $\$ 500$ for each violation").

${ }^{73}$ Cassuto, supra note 28, at 8; see also Robyn Mallon, The Deplorable Standard of Living Faced by Farm Animals in America's Meat Industry and How to Improve Conditions by Eliminating the Corporate Farm, 9 Mich. ST. Univ. J. MED. \& L. 389, 399 (2005).

${ }^{74}$ See infra notes 75-122 and accompanying text. 
laws' respective ambits. ${ }^{75}$ The statutes are drafted in such a way as to make common (and cruel) agricultural practices acceptable, make enforcing the law impracticable, and render offenders immune from prosecution. ${ }^{76}$

Traditionally, domestic animals were viewed as property to be used as the owner saw fit. ${ }^{77}$ However, when animals gained economic value, they acquired some limited legal protections, as well. ${ }^{78}$ Today, that relationship is inverted. Animals that were historically unprotected, such as domestic pets, have more legal protection than commoditized animals. ${ }^{79}$ Companion animals enjoy more protection than other animals because of their special relationship with humans. ${ }^{80}$ Farm animals, on the other hand, are generally ex-empted from anticruelty laws because they are viewed as an instrument of production and a means to human ends. The laws are predicated on the notion that "it would harm a human being to observe or [have] knowledge [of] the infliction of harm on a companion animal, while it may not harm them if pain were inflicted on an animal they solely use as a means to an end." 81 This attitude underlies a commonly held notion that anti-cruelty laws are less concerned with protecting animals than with the morality and well-

${ }^{75}$ See, e.g., S.C. CODE ANN. § 47-1-40(C) (2015) (providing that the statute does not apply to fowl and "accepted animal husbandry practices of farm operations").

${ }^{76}$ See COLO. REv. STAT. § 18-9-201.5 (2015) (stating that the act shall not affect accepted husbandry practices); IDAHO CODE $§ 25-3514$ (5) (2015) (providing that the statute shall not inter-fere with normal or accepted practices of animal husbandry); Mo. REV. STAT. § 578.007(8) (2015) (stating that the act shall not apply to "normal or accepted practices of animal husbandry"); see also Wolfson, supra note 2, at 123 (explaining that twenty-eight states have enacted laws that create a legal realm whereby certain acts, no matter how cruel, are outside the reach of anti-cruelty statutes as long as the acts are deemed "accepted," "common," "customary," or "normal" farming practices). See generally Christopher A. Pierce, Detailed Discussion of Humane Societies and Enforcement Powers, MICH. ST. U. ANIMAL LEGAL \& HISTORICAL CTR. (2011), https://www.animal

law.info/article/detailed-discussion-humane-societies-and-enforcement-powers [http://perma.cc/ 93VW-34VV] (describing how some states delegate enforcement authority to humane societies because of difficulties in traditional enforcement).

${ }^{77}$ Wolfson, supra note 2, at 127 (owners of domesticated animals were free to treat animals as they wished and dispose of them as they wished).

${ }^{78}$ DAVID FAVRe \& MurRay Loring, ANIMAL LaW 122 (1983) (explaining how domesticated animals that were valuable in economic terms gained statutory protections against their theft and destruction); Wolfson, supra note 2, at 127 ("Only when animals gained economic value did the law prohibit the interference with such animals by someone other than the owner.").

${ }^{79}$ FAVRE \& LORING, supra note 78, at 122; Wolfson, supra note 2, at 127.

${ }^{80}$ Paige M. Tomaselli, Detailed Discussion of International Comparative Animal Cruelty Laws, Mich. ST. U. ANiMAL LEgAL \& HistoriCAL CTR. (2003), https://www.animallaw.info/article/ detaileddiscussion-international-comparative-animal-cruelty-laws [http://perma.cc/XTJ6-RXAT].

${ }^{81} I d$. (internal quotations omitted). 
being of humans. ${ }^{82}$ The idea that humans form the focus of anti-cruelty laws has found its way into the jurisprudence, as well. ${ }^{83}$

\section{a. Statutory Construction}

As noted, many states explicitly exempt agricultural animals from cruelty protections. Thirty-seven states exempt "common" or "normal" farming practices from legal scrutiny. ${ }^{84}$ Thus, no matter how cruel a practice might be, if commonly done, it becomes legally permissible. ${ }^{85}$ Other states, like Iowa and Utah, exclude livestock from the statutory definition of "animal," leaving them with virtually no protection at all. ${ }^{86}$

Allowing the regulated community to base what is and is not permissible on industry practice goes beyond self-regulation; it points to a regulatory matrix devoid of any real function. ${ }^{87}$ In this void, the commonality of a practice, rather than any normative analysis, becomes the barometer of ac-ceptability. Commentators David Wolfson and Mariann Sullivan liken this approach to the fox guarding the henhouse. ${ }^{88}$ Professor J.B. Ruhl-referring to a similar indifference to the industry's environmental impacts - calls it "the vast 'anti-law' of farms and the environment." 89

\section{${ }^{82}$ See id.}

${ }^{83}$ See People v. Garcia, 812 N.Y.S.2d 66, 73 (2006) (concluding that killing goldfish in front of a small child amounts to aggravated cruelty because of the distress caused to the child); Chiesa, supra note 33 , at 1.

${ }^{84}$ Cody Carlson, How State Ag-Gag Laws Could Stop Animal-Cruelty Whistleblowers, ATLANTIC (Mar. 25, 2013), http://www.theatlantic.com/politics/archive/2013/03/how-state-ag-gaglaws-could-stop-animal-cruelty-whistleblowers/273962/ [http://perma.cc/3LT5-BYVK].

${ }_{86}^{85}$ See Wolfson, supra note 2, at 136.

${ }^{86}$ IOWA CODE § 717B.1(1)(a) (2015) (stating that “"animal' does not include ... [1]ivestock"); UTAH CODE ANN. § 76-9-301(1)(b)(ii) (West 2015) (stating that “"[a]nimal' does not include ... [1]ivestock").

${ }^{87}$ See Colo. Rev. StAT. § 18-9-201.5 (2015) ("Nothing in this part . . . shall affect accepted animal husbandry practices . . .."); IDAHO CODE § 25-3514 (2015) ("No part of this chapter shall be construed as interfering with ... [n]ormal or accepted practices of animal identification and animal husbandry as established by, but not limited to, guidelines developed and approved by the appropriate national or state commodity organizations ... ."); 510 ILL. COMP. STAT. 70/13 (2015) ("Nothing in this Act affects normal, good husbandry practices utilized by any person in the production of food, companion or work animals ....”); IOWA CODE § 717.2(1) (livestock neglect does not include conduct consistent with "customary animal husbandry practices"); MONT. CODE ANN. § 45-8-211(4) (2015) ("This section does not prohibit . . . the use of commonly accepted agricultural and livestock practices on livestock . . . ."); NEv. REv. STAT. § 574.200 (2015) ("The[se] provisions . . . do not . . . [p]rohibit or interfere with established methods of animal husbandry, including the raising, handling, feeding, housing and transporting of livestock or farm animals."); see also Wolfson, supra note 2, at 127-32; Wolfson \& Sullivan, supra note 6, at 207.

${ }^{88}$ Wolfson \& Sullivan, supra note 6, at 207. 
${ }^{89}$ J.B. Ruhl, Farms, Their Environmental Harms, and Environmental Law, 27 ECOLOGY L.Q. 263, 267 (2000). 
Another way states limit protections for agricultural animals is through a seemingly deliberate lack of clarity in defining the nature of any purported offense. $^{90}$ Poor draftsmanship and vague terminology leave courts with broad discretion to determine if and how farm animals fall within the law's scope. ${ }^{91}$ In addition, even statutes that cover agricultural animals frequently exclude requirements regarding their basic needs. ${ }^{92}$ These omissions include minimum requirements for adequate exercise, space, light, ventilation, and clean living conditions. ${ }^{93}$

\section{b. Enforcement}

Aside from the myriad of exemptions and exclusions embedded in state laws, practical enforcement issues further hinder farm animal protections. ${ }^{94}$ For example, if a statute has a mens rea requirement and an industrial facility houses hundreds of thousands of animals, it becomes very difficult to prove that the neglect and consequent suffering of specific animals in the facility was deliberate rather than the result of ignorance or simple negligence. ${ }^{95}$ Furthermore, resources for prosecuting crimes against animals often disappear in the face of relentless pressure to prioritize crimes against human victims. ${ }^{96}$ This budget squeeze presents additional difficulties be-

${ }^{90}$ Wolfson \& Sullivan, supra note 6 , at 207-14.

${ }^{91}$ Wolfson, supra note 2, at 131; see, e.g., State v. Stockton, 333 P.2d 735, 737 (Ariz. 1958) ("Our conclusion is that the legislature did not express an intention to include birds or fowls within . . . the term 'an animal."'); State v. Buford, 331 P.2d 1110, 1115 (N.M. 1958) ("The language of the statute, however, seems to apply only to brute creatures and work animals."); Lock v. Falkenstine, 380 P.2d 278, 283 (Okla. Crim. App. 1963) ("[T]he Oklahoma Statute makes no attempt to define animals, yet the legislature has described the species that come under certain provisions; and the Court is at a loss to ascertain why that was not done in the Statute before us.").

${ }^{92}$ See VT. STAT. ANN. tit. 13, § 382 (2015) (transportation statute allowing transport without food, water, and rest for up to eighteen hours); WIS. STAT. § 951.14 (2013-2014) (requiring provi-sion of proper shelter, but does not require provisions any more stringent than normally accepted husbandry practices). Light is only a requirement in a few state statutes, and only Maine and Wis-consin refer to clean living conditions in their statutes. ANIMAL WeLFARE INST., ANIMALS AND THEIR LEGAL RightS: A Summary of American Laws from 1641-1990, at 10 (1990) (citing Me. Stat. tit. 7, § 4011 (2015)).

${ }^{93}$ Wolfson, supra note 2, at 131 (citing ANIMAL Welfare INST., supra note 92, at 10); ME. STAT. tit. 7, $\$ 4011$ (describing how in Maine, it is unlawful to "[d]eprive an animal that the person owns or possesses of necessary sustenance, necessary medical attention, proper shelter, protection from the weather or humanely clean conditions").

${ }_{95}^{94}$ See infra notes 95-106 and accompanying text.

${ }^{95}$ See Wolfson, supra note 2, at 131 (noting that "many state statutes require that the prosecution demonstrate a mental state of the defendant that may be hard to prove").

${ }^{96} I d$. (citing and quoting Steven Wise, Of Farm Animals and Justice, 3 PACE ENVTL. L. ReV. 191, 206 (1986)) ("“[T]he enforcement of these criminal statutes is typically left to a public prosecutorial agency, itself overwhelmed by human problems, or to an overburdened private Society for 
cause state anti-cruelty laws provide no standing for private parties. ${ }^{97}$ Thus, if the state declines to prosecute a violation, there is no other recourse.

Moreover, even if a state were to enforce its anti-cruelty policies, police officers may lack the training and expertise to identify crimes and enforce the laws. ${ }^{98}$ Several states delegate police powers to humane societies and their agents. ${ }^{99}$ For example, in New York, the American Society for the Prevention of Cruelty to Animals has broad authority to investigate and enforce animal cruelty violations. ${ }^{100}$ Sometimes, delegation of enforcement authority involves specialized individuals endorsed by humane societies who work alongside police officers. ${ }^{101}$ On the other end of the spectrum, humane society agents may be granted all enforcement authority, essentially resulting in the deputization of humane society employees. ${ }^{102}$ Relegating animal protection to the purview of non-governmental organizations undermines the status of the endeavor and leaves it to the mercy of privately funded organizations. 103

It also bears mentioning that because farming practices largely take place on private property, law enforcement is hindered because of the difficulty of establishing the required probable cause to enter the premises where the alleged violation is taking place. ${ }^{104}$ Attaining probable cause often requires having a person on the inside documenting the criminal activi-

the Prevention of Cruelty to Animals (SPCA) or similar society, with no private enforcement right."').

${ }^{97}$ See generally William A. Reppy, Jr., Citizen Standing to Enforce Anti-Cruelty Laws by Obtaining Injunctions: The North Carolina Experience, 11 ANIMAL L. 39 (2005) (describing how North Carolina is the only state that authorizes citizen standing for the enforcement of anti-cruelty laws); Kristen Stuber Snyder, Note, No Cracks in the Wall: The Standing Barrier and the Need for Restructuring Animal Protection Laws, 57 Clev. ST. L. REv. 137 (2009) (discussing the difficulties of establishing standing in animal welfare cases).

${ }^{98}$ See Pierce, supra note 76. See generally Resources for Law Enforcement, HuMANE SOC'Y OF THE U.S., http://www.humanesociety.org/issues/abuse_neglect/resources_law_enforcement.html [http://perma.cc/NJ72-E9D7] (discussing that law enforcement agencies across the country call upon the Animal Rescue Team to assist with the investigation and prosecution of animal abuse).

${ }^{99}$ Pierce, supra note 76.

${ }^{100}$ N.Y. Crim. Proc. Law § 2.10(7) (McKinney 2015).

${ }_{101}^{10 e}$ Pe Pierce, supra note 76.

${ }^{102}$ Id. (detailing how California approves humane officers, giving them nearly all the powers of a police officer, and may allow them to carry a firearm).

${ }^{103}$ Wolfson, supra note 2, at 147 ("The delegation of power to the farming industry is breathtaking. It is difficult to imagine another non-governmental group possessing such influence over a criminal legal definition. In effect, state legislators have granted agribusiness a 'legal license' to treat farm animals as they wish.").

${ }^{104} I d$. at 132 ("It is ... extremely difficult to ascertain what occurs on the average farm, be-cause a farm is private property."). 
ty. ${ }^{105}$ Yet, many states have criminalized the undercover operations that expose the animal abuse. ${ }^{106}$

\section{c. State Level Ag-Gag Legislation}

Ag-gag laws "criminalize the recordings, possession, or distribution of still images (photos), live images (video) and/or audio at or upon a farm, industrial agricultural operation, or animal facility." 107 In the 1980s, the predecessors of ag-gag laws sought to prevent theft or injury to farmed animals. ${ }^{108}$ However, in their contemporary form, these laws now prohibit the production of unauthorized audio/visual recordings at agricultural facilities and the possession and distribution of recordings. ${ }^{109}$

While proponents of aggag legislation claim that such laws are necessary for the protection of agricultural enterprises against defamation and misrepresentation, numerous organizations with focuses ranging from civil liberties, public health, food safety, environmental, food justice, animal welfare, legal, workers' rights, to free speech oppose aggag laws as a violation of the First Amendment. ${ }^{110}$ Ultimately, such laws bolster the ability of the agricultural industry to keep inhumane practices behind closed doors, free from the threat of prosecution or public opprobrium. ${ }^{111}$

Existing laws such as trespass already criminalize much of the behavior criminalized by aggag laws. ${ }^{112}$ However, ag-gag laws drastically in-

${ }^{105} I d$. (citing State v. Osborn, 409 N.E.2d 1077 (Ohio 1980)).

${ }^{106}$ See id. (pointing to the significant trend within states to remove legal protection from ani-mals raised for food or food production altogether).

${ }^{107}$ Abigail Perdue \& Randall Lockwood, Animal Cruelty and Freedom of Speech: When WORLDS COLLIDE 232 (2014).

${ }^{108}$ Sonci Kingery, Note, The Agricultural Iron Curtain: Ag Gag Legislation and the Threat to Free Speech, Food Safety, and Animal Welfare, 17 Drake J. Agric. L. 645, 656 (2012) (stating that "the Kansas law was less focused on undercover investigations and more concerned with property damage and liberation or theft of animals").

${ }^{109}$ See, e.g., IOWA CODE § 717A.3A (2015); Mont. CODE ANN. § 81-30-103(2)(e) (2015); UtAh CoDE ANN. § 76-6-112(2)(a)-(d) (West 2015).

${ }^{110}$ See Kathleen Masterson, Ag-Gag Law Blows Animal Activists' Cover, NPR (Mar. 10, 2012), http://www.npr.org/2012/03/10/148363509/ag-gag-law-blows-animal-activists-cover [http:// perma.cc/T3G6-6883] (explaining how ag-gag laws can silence workers who see abuse and film it, and in turn, infringe upon their right to free speech). See generally Kevin C. Adam, Note, Shooting the Messenger: A Common-Sense Analysis of State "Ag-Gag" Legislation Under the First Amendment, 45 Suffolk U. L. ReV. 1129 (2012) (discussing the inherent conflict between ag-gag laws and First Amendment rights).

${ }^{111}$ Mark Bittman, Who Protects the Animals?, N.Y. Times (Apr. 26, 2011 9:29 PM), http:// www.opinionator.blogs.nytimes.com/2011/04/26/who-protects-the-animals [http://perma.cc/CZ6C-JLPN]. 
${ }^{112}$ Trespass, BLACK's LAW DiCTIONARY (10th ed. 2014) (defining trespass as "[a]n unlawful act committed against the . . property of another" or "wrongful entry on another's real property"). 
crease the severity of the penalties for such violations, based solely on the media's content and the actor's intent. ${ }^{113}$ As such, they raise serious constitutional questions. ${ }^{114} \mathrm{~A}$ number of governors have vetoed ag-gag legislation and several others are facing court challenges. ${ }^{115}$

Ag-gag laws also present an interesting irony similar to the inversion of necessity in animal cruelty laws. Just as animal cruelty laws define necessity in terms of the needs of the person inflicting the cruelty, aggag laws are designed to protect those who inflict cruelty, while criminalizing those who expose it. ${ }^{116}$ Thus, victimized animals are completely ignored by the legal system while those who victimize them receive the extensive protection. Under Idaho's recently overturned aggag statute, for example, violations could have led to up to a year in jail and a \$5,000 fine. ${ }^{117}$ Yet, the maximum jail time for a first violation of the state's animal cruelty statute was six months. ${ }^{118}$ Thus, the law would have "punish[ed] those who expose animal cruelty more severely than those who actually commit[ed] it."119

In sum, agricultural animals in the United States have almost no legal protection from birth to slaughter. ${ }^{120}$ Given this reality, the question becomes whether improved legislation would cure existing deficiencies and provide adequate safeguards against inhumane agricultural practices. As the ensuing discussion of Brazil's legal regime makes clear, even impressive

${ }^{113}$ See, e.g., Kan. Stat. AnN. § 47-1827(c) (2014); Mont. Code AnN. § 81-30-103.

${ }^{114}$ See Adam, supra note 110, at 1169 (discussing how ag-gag laws are likely an unconstitutional content-based restriction on speech).

${ }^{115}$ See, e.g., Civil Rights Complaint at 2, Animal Legal Def. Fund v. Herbert, No. 13-679 (D. Utah filed July 22, 2013), http://www.mediapeta.com/peta/pdf/PETAALDFUtahAgGag Complaint.pdf [http://perma.cc/8SVC-CHM2] (challenging Utah's ag-gag law as unconstitutional, claiming that it violates the Supremacy Clause and First and Fourteenth Amendments); Jessalee Landfried, Note, Bound \& Gagged: Potential First Amendment Challenges to “Ag-Gag” Laws, 23 DuKE ENVTL. L. \& POL'Y F. 377, 391-401 (2013) (pointing out weaknesses in First Amendment challenges to existing and proposed ag-gag laws); Samantha Lachman, North Carolina Gov. Pat McCrory Defies GOP Legislature, Vetoes 'Ag-Gag' Bill, HufFInGTON POST (May 29, 2015, 3:51 PM),

http://www.huffingtonpost.com/2015/05/29/pat-mccrory-ag-gag-_n_7471210.html [http:// perma.cc/5M7E-BEUS] (North Carolina Governor Pat McCrory vetoing ag-gag bill over concerns that it could criminalize employees who report illegal activity); Andy Sher, Tennessee Governor Bill Haslam

Vetoing 'Ag-gag' Bill, TiMES FREE PRESS (May 13, 2013), http://www.timesfreepress.

com/news/local/story/2013/may/13/tennessee-governor-bill-haslam-vetoing-ag-gag-bill/107867/

[http://perma.cc/29L8-SAZT] (Tennessee Governor Bill Haslam vetoing ag-gag bill, citing First

Amendment concerns).

${ }^{116}$ See Landfried, supra note 115 , at 391.

${ }^{117}$ See IDAHo CodE § 18-7042(1) (2015); Animal Legal Def. Fund v. Otter, No. 14-104,

2015 WL 4623943, at *3 (D. Idaho Aug. 3, 2015).

${ }^{118}$ See IDAHO CODE § 25-3520A(1).

${ }^{119}$ Civil Rights Complaint at II 50, Animal Legal Def. Fund v. Otter, 44 F. Supp. 3d 1009 (D. Idaho 2014) (No. 14-104), 2014 WL 1017045 , at*1.

${ }^{120}$ See supra notes 41-119 and accompanying text.

Revista Juris Poiesis - Rio de Janeiro. Vol.21-n²5, 2018, pg.211-270 252. ISSN 2448-0517 -

Rio de Janeiro, 29 de abril de 2018. 
legislation coupled with constitutional rights cannot overcome countervailing economic and social forces. ${ }^{121}$ Therefore, more than simply stronger laws are needed; the entire regulatory regime needs to be reformed. ${ }^{122}$

\section{B. Regulation in Brazil}

Brazil's animal welfare regime dates to 1924, when the federal government enacted Decree 16.560/1924, prohibiting the "carrying out of any behavior or recreation that cause[s] suffering to animals." 123 A decade later, in 1934, then President Getulio Vargas promulgated Decree 24.645, which prohibited:

[Maintaining] animals in anti-hygienic places or where they can-not breath properly, move or rest, or are deprived of light; . . .

abandon[ing] [an] animal that is ill, hurt, worn out or mutilated, and also not giving to it everything that is possible, including veterinary assistance; ... [ [or] not giving quickly death, without long suffering, for an animal for which extermination is necessary for consumption or not .... ${ }^{124}$

The law also enabled lawyers from the Public Ministry, or attorneys from animal protection organizations to assist animals in court. ${ }^{125}$ This gives animals a form of standing in federal court that is wholly lacking in the United States. ${ }^{126}$ The Public Ministry or Public Prosecutor's Office is considered a fourth branch of the Brazilian government. ${ }^{127}$ Completely autonomous and separate from the legislative, judicial, and executive branches, its sole pur - pose is to oversee compliance with the law and defend national interests. ${ }^{128}$

${ }^{121}$ See infra notes $123-178$ and accompanying text.

${ }^{122}$ See supra note 47 and accompanying text.

${ }^{123}$ Decreto No. 16.560, de 16 de Agosto de 1924, Diário Oficial DA UNIÃo [D.O.U.] de 16.8.1924 (Braz.); Silva, supra note 11, at 83.

${ }^{124}$ Brazil Federal Decree on Anti-Cruelty No. 24,645, Мich. ST. U. Animal Legal \& HISTORICAL CTR., https://www.animallaw.info/administrative/br-federal-decree-anti-cruelty [http:// perma.cc/4VZS-T3P4] (providing a summary, in English, of Decree 25.645); see Decreto No. 24.645, de 10 de Julho de 1934, DiáRIO OfICIAL DA UNIÃo [D.O.U.] de 10.07.1934 (Braz.); Cassuto \& Saville, supra note 8, at 202.

${ }^{125}$ Decreto No. 25.645, de 10 de Julho de 1934, Diário Oficial Da União [D.O.U.] de 10.07.1934 (Braz.).

${ }^{126}$ Silva, supra note 11 , at 83 .

${ }^{127}$ Lesley McAllister \& Benjamin van Rooij, Environmental Challenges in Middle-Income Countries: A Comparison of Enforcement in Brazil, China, Indonesia, and Mexico, in LAW AND

Revista Juris Poiesis - Rio de Janeiro. Vol.21-n²5, 2018, pg.211-270 252. ISSN 2448-0517 -

Rio de Janeiro, 29 de abril de 2018. 
DEVElopment of Middle-Income Countries:

Avoiding the Middle-Income TRAP 288, 288-306 (Randall Peerenboom \& Tom Ginsberg eds., 2014).

${ }^{128}$ Learn More About the Public Ministry of Brazil, PORTAL BRAZ., http://translate.google.com/ translate?sl=auto\&tl=en\&js=n\&prev=_t\&hl=en\&ie=UTF-8\&u=http\%3A\%2F\%2Fwww.brasil.gov . 
One of the most significant legal developments involving animal protection in Brazil (or anywhere) was the enactment of the Brazilian Constitution of 1988, which explicitly recognizes fundamental rights for animals. ${ }^{129}$ Article 225 states that:

All [people] have the right to an ecologically balanced environ-ment, which is an asset of common use and essential to a healthy quality of life, and both the Government and the community shall have the duty to defend and preserve it for present and future generations.

Paragraph 1-In order to ensure the effectiveness of this right, it is incumbent upon the Government to . . . protect the fauna and the flora, with prohibition, in the manner prescribed by law, of all practices which represent a risk to their ecological function, cause the extinction of a species or subject an animal to cruelty. ${ }^{130}$

Since the Constitution's enactment, animal protection laws have gained broader acceptance. ${ }^{131}$ One important milestone was the 1998 enactment of Article 32 of the Environmental Criminal Act (the "Act"), criminalizing abuse, mistreatment, injury, and mutilation of domestic animals. ${ }^{132}$ Violating this act can result in fines and/or imprisonment ranging from three months to one year. ${ }^{133}$

Even if the animal's suffering was inflicted for a scientific or educational purpose, perpetrators may still be liable if they failed to seek out alternative approaches. ${ }^{134}$ However, as with U.S. anti-cruelty laws, Brazil's Environmental Criminal Act does not protect agricultural animals. ${ }^{135}$ For

br\%2Fgoverno\%2F2010\%2F01\%2Fministerio-publico\&act=ur $\quad$ [https://perma.cc/VZR5-N54P] (last updated July 28, 2014).

${ }^{129}$ E. BRADFORD BURNS, A HISTORY OF BRAZIL 500 (1994) (stating that the 1988 Constitu-tion was the fifth constitution since Brazil gained independence from Portugal in 1822, and was the first since Brazil became a democracy following the end of the military dictatorship in 1985).

${ }^{130}$ Constituição Federal [C.F.] [Constitution] art. 225 (Braz.) (emphasis added).

${ }^{131}$ Edna Cardoza Dias, A Defesa dos Animais e as Conquistas Legislativas do Movimento de Proteção Animal no Brasil, 2 Brazilian ANimal Rights Rev. 149, 160-61 (2007).

132 See Lei No. 9.605, Art. 32, de 12 de Fevereiro de 1998, Diario Oficial Da UniaO

[D.O.U.] de 13.2.1998 (Braz.); Cassuto \& Saville, supra note 8, at 202.

${ }^{133}$ See Lei No. 9.605, Art. 32, de 12 de Fevereiro de 1998, Diario OfICIAL DA UniaO [D.O.U.] de 13.2.1998 (Braz.); Cassuto \& Saville, supra note 8, at 202; Lane Azevedo Clayton, Overview of Brazil's Legal Structure for Animal Issues, Mich. ST. U. ANiMAL LEGAL \& HistoricAl CTR.

(2011), https://www.animallaw.info/article/overview-brazils-legal-structure-animal-issues [http: perma.cc/Q2WN-H5Z9].

${ }^{134}$ Clayton, supra note 133 , at 4; see Gallegos, supra note 11 (describing event during which Brazilian animal-rights activists liberated hundreds of beagles undergoing laboratory testing to make a statement about animal welfare and rights).

${ }^{135}$ Silva, supra note 11 , at 86 . 
example, Article 37 of the Act, entitled "Crimes against Fauna," appears to cover wild and domesticated animals. ${ }^{136}$ Yet, the provision addressing slaughter only provides for the legality of killing wild animals and hunting for subsistence purposes - i.e., when it is carried out to satisfy a necessity of hunger. ${ }^{137}$ Omitting agricultural animals from this provision leaves them in a legal limbo. While the legislature did not intend to outlaw the commercial slaughter of animals, the extent to which it meant to regulate the practice remains unclear. ${ }^{138}$

Beyond general statutes prohibiting cruelty, Brazil, like the United States, also has rules and guidance governing animal treatment during and resulting from transport. ${ }^{139}$ The Regulation of Industrial and Health Inspection of Products of Origin Act (2005) states that "animals must remain at the lairage for rest and fasting for 24 hours." 140 This requirement provides a mandatory resting period in special resting pens before slaughter. ${ }^{141}$ This lairage requirement period can be reduced depending on the distance the animal has traveled. ${ }^{142}$ Moreover, like the United States, Brazil also excludes birds from laws governing transport or export that affect the welfare of the animal. ${ }^{143}$ However, unlike the United States, Brazil's humane slaughter laws $d o$ apply to birds in addition to mammals. ${ }^{144}$ Whether these

${ }^{136}$ See Lei No. 9.605, Art. 37, de 12 de Fevereiro de 1998, Diario OFICIAL DA UNIAO

[D.O.U.] de 13.2.1998 (Braz.).

${ }^{137}$ See id.

${ }^{138}$ See Silva, supra note 11 , at 86.

${ }^{139}$ See, e.g., Decreto No. 24.548, de 3 de Julho de 1934, Diario Oficial DA Uniao [D.O.U.] de 3.7.1934 (Braz.) ("When transported by railroad, field animals that are destined for slaughter may not be kept on board for periods of more than 72 hours."); Decreto No. 5.741, de 30 de Março de 2006, DIARIO OFICIAL DA UNIAO [D.O.U.] de 30.3.2006 (Braz.); Instrução Normativa No. 18, de 18 de Julho de 2006, DiARIO OfICIAL DA UNIAO [D.O.U.] de 18.7.2006 (Braz.). For more examples, see MinisTRY OF AGRic., Livestock \& Food SupPly, Legislation Manual: National ANimal Health PRograms IN BRAZIL (2009), http://ww3.panaftosa.org.br/Comp/ MAPA/ManuaisTecnicos/ManualLegislacao/LegislationManualOK.pdf [perma.cc/8FTL-6YCJ].

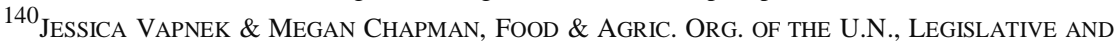
REGULATORY OPTIONS FOR ANIMAL WELFARE 51 (2010), http://www.fao.org/docrep/013/ i1907e/i1907e00.pdf [http://perma.cc/9AF7-9KYJ].

141 Decreto No. 30.691, de 29 de Março de 1952, Diario Oficial da Uniao [D.O.U.] de 29.3.1952 (Braz.).

${ }^{142}$ VAPNEK \& CHAPMAN, supra note 140 , at 51; Lairage, OXFORD DICTIONARY, http://www. oxforddictionaries.com/us/definition/american_english/lairage [http://perma.cc/5QHJ-MMCV] (defining "Lairage" as "a place where cattle or sheep may be rested on the way to market or slaughter").

${ }^{143}$ See Cassuto \& Saville, supra note 8, at 202-03.

${ }^{144}$ See Decreto No. 94.554, de 24 de Juhlo de 1987, Diário Oficial DA União [D.O.U.] de 24.7.1987 (Braz.) (addressing standards for housing and slaughter of commercial animals, including birds); Instrucao Normativa No. 3, de 17 de Janeiro de 2000, DiÁRIO OfICIAL DA UnIÃo [D.O.U.] de 17.1.2000 (Braz.) (addressing minimum requirements for humane slaughter, including birds); Portaria 
No. 85, de 18 de Novembro de 1988, DiÁRIO Oficial DA UNIÃO [D.O.U.] de 18.11.1988 (Braz.) (concerning standards for general conditions of operation for 
humane standards, on a practical level, are imputed into export and transport legislation remains an open question. ${ }^{145}$

The Brazilian government has also worked with the agricultural industry to implement what it terms "Good Agricultural Practices." 146 This pro-gram was developed by the Brazilian Agricultural Research Corporation to implement recommended standards for "vegetables, maize, soybeans, man-goes, melons, beef, milk, swine and broiler production."147 Specifically, the program propounds general guidelines for cattle welfare. ${ }^{148}$ Yet, as is evident from the linking of animals and vegetables, the emphasis lies on the quality of the eventual food rather than the animals' wellbeing. The focus remains always on the food. ${ }^{149}$

Brazil's Good Agricultural Practice standards are worth comparing to those of the European Union ("EU"). ${ }^{150}$ The most significant difference is that in Brazil, the decision to adopt the Good Agricultural Practice standards is voluntary, not mandatory. ${ }^{151}$ EU guidelines include a comprehensive approach predicated on the understanding that animals are "sentient beings" and should be treated in such a way that they do not suffer unnecessarily. ${ }^{152}$ All EU animal welfare directives emphasize the Five Freedoms:

\section{Freedom from hunger and thirst - access to fresh water and a diet for full health and vigor;}

small and averaged-sized slaughterhouses, which includes birds); see also Cassuto \& Saville, supra note 8, at 202-03 (explaining that Brazil, unlike the United States, has laws specific to humane slaughter of poultry as well as mammals).

${ }^{145}$ See Cassuto \& Saville, supra note 8, at 202-03.

146 BRAZILIAN AGRIC. RESEARCH CORP., GUIDELINES FOR GOOD AGRICULTURAL PRACTIC-

ES: EMBRAPA'S INPUT TO FAO'S PRIORITY AREA OF INTERDISCIPLINARY ACTION ON INTEGRAT-ED PRODUCTION SYSTEMS 7 (2002), http://www.fao.org/prods/gap/docs/pdf/guidelines_for__good_ agricultural_practices.pdf [http:perma.cc/F2GV-95YF]; Cassuto \& Saville, supra note 8, at 203.

${ }^{147}$ BRAZILIAN AGRIC. RESEARCH CORP., supra note 146 , at 7.

${ }^{148}$ VAPNEK \& CHAPMAN, supra note 140, at 53 (explaining that it is essential to provide animals with a comfortable and safe environment, freedom of movement, and protection against stress, illness, pain, or unnecessary harms).

${ }^{149}$ BraZiLIAN AgRic. ReseARCH CORP., supra note 146, at 7.

${ }^{150}$ See Cassuto \& Saville, supra note 8, at 203.

${ }^{151}$ Se e VAPNEK \& CHAPMAN, supra note 140, at $31 \mathrm{n} .22$ (highlighting Brazilian Program of Good Agricultural Practices as an example of non-binding best practice codes developed by industry associations).

${ }^{152}$ See Communication from the Commission to the European Parliament, the Council and the European Economic and Social Committee on the European Union Strategy for the Protection and Welfare of Animals 2012-2015, EU COM (2012) 006 final (Jan. 19, 2012) ("Article 13 of the Treaty on the Functioning of the European Union recognizes animals as sentient beings and requires full regard be given to the welfare requirements of animals while formulating and enforcing some EU policies.”). 
2. Freedom from discomfort - an appropriate environment with shelter and comfortable rest areas;

3. Freedom from pain, injury and disease — prevention or rapid treatment;

4. Freedom to express normal behavior - adequate space and facilities, company of the animal's own kind;

5. Freedom from fear and distress - conditions and treatment which avoid mental suffering. ${ }^{153}$

In 1998, the EU enacted welfare legislation for agricultural animals to ensure that "owners or keepers take all reasonable steps to ensure the welfare of animals under their care and to ensure that those animals are not caused any unnecessary pain, suffering or injury." 154 The directive enumerates specific requirements including freedom of movement, air circulation, adequate lighting, and appropriate food and water supplies. ${ }^{155}$

In 2009, the EU also mandated that "[n]o person shall transport animals or cause animals to be transported in a way likely to cause injury or undue suffering to them." 156 Finally, EU standards for slaughter aim to avoid pain and minimize the stress and suffering endured by farm animals during the process. ${ }^{157}$ The regulation heightened operator responsibilities, imposed stricter standards, and increased training and research. ${ }^{158}$ These standards are mandatory in all EU member countries. ${ }^{159}$

Though Brazil's Good Agricultural Practices conform with or exceed EU animal welfare standards and while many Brazilian producers participate, the Brazilian guidelines are voluntary. ${ }^{160}$ Consequently, inhumane treatment remains entrenched throughout the industry. ${ }^{161}$ In an effort to ad-dress these and other animal welfare issues, the Brazilian Ministry of Agriculture, Livestock and Food Supply established the Permanent Technical Commission on Animal Welfare ("MAPA"). ${ }^{162}$

\footnotetext{
${ }^{153}$ Directorate Gen. FOR HeAlth \& CONSUMER Prot., supra note 9 , at 1.

${ }^{154}$ Council Directive 98/58/EC, art. 3, 1998 O.J. (L 221) 1 (EC).

${ }^{155} I d$. at Annex.

${ }_{156}$ Council Regulation 1/2005, art. 3, 2004 O.J. (L 3) 1 (EC).

${ }^{157}$ See Council Regulation 1099/2009, ch. 2, art. 3, 2009 O.J. (L 303) 1 (EC).

${ }^{158}$ See id.

${ }^{159}$ Council Regulation 1/2005, art. 3, 2004 O.J. (L 3$) 1$ (EC).

${ }^{160}$ See VAPNEK \& CHAPMAN, supra note 140, at $31 \mathrm{n} .22$ (highlighting Brazilian Program of
}

Good Agricultural Practices as an example of non-binding best practice codes developed by industry associations).

${ }^{161}$ Cassuto \& Saville, supra note 8, at 203; see, e.g., Harald Grethe, High Animal Welfare Standards in the EU and International Trade-How to Prevent Potential 'Low Animal Welfare Havens'?, 32 FOOD POL'y 315, 318 (2007).

${ }^{162}$ MinisTRY OF AGRIC., LIVESTOCK \& FOOD SUPPLy, ANIMAL WELFARE IN BRAZIL (n.d.), http://www.abiec.com.br/img/folder-animal-welfare.pdf [http://perma.cc/B396-U4CD]. 


\section{Among other responsibilities, MAPA's portfolio requires that it:}

[D]evelop and propose legislation, standards and technical rec-ommendations of good practices for Animal Welfare; encourage and promote events related to the Commission's target topic; promote training of all involved in the livestock chain; articulate with representative entities of the livestock and research sectors; propose publication and dissemination of technical material and information on animal welfare [and] encourage and propose agreements, covenants and terms of cooperation with public and private entities to promote actions linked to Animal Welfare. ${ }^{163}$

Additionally, MAPA collaborated with the World Society for the Protection of Animals ("WSPA") to initiate the "Steps" program. ${ }^{164}$ Steps is concerned with "theoretical and on-site training on pre-slaughter and humane slaughter practices." 165 The WSPA contracted with MAPA to provide veterinarians in Brazil with training in animal welfare standards. ${ }^{166}$ Lastly, MAPA officially acknowledged the Brazilian Poultry Union's voluntary animal welfare pro-tocol for broiler chickens and turkeys. ${ }^{167}$ As in the United States, chickens and turkeys make up a very high percentage of agricultural animals in Bra-zil. ${ }^{168}$ Thus, having some protections in place for them is highly significant. While MAPA's acknowledgement and collaboration with the WSPA do not create actual legal protections for animals, they nonetheless support animal welfare goals and complement currently available regulatory and legal measures. ${ }^{169}$

Amidst these existing regulations and voluntary standards, Brazilian agricultural animals continue to endure hardships over and above those inherent to the meat and dairy industries. ${ }^{170}$ For example, in the last decade,

${ }^{163}$ Id.

${ }^{164}$ Rosangela Poletto \& Maria J. Hotzel, The Five Freedoms in the Global Animal Agriculture Market, Challenges and Achievements as Opportunities, 2 ANIMAL FRONTIERS 22, 28 (2014).

${ }^{165}$ Id.

${ }^{166}$ See id. at $26-27$.

${ }_{167}^{16}$ See id. at 26.

168 See generally U.S. DeP'T OF AGRIC., LiVESTOCK AND POUlTRY: WORLD MARKETS AND TRADE (2015), http://apps.fas.usda.gov/psdonline/circulars/livestock_poultry.pdf [http://perma.cc/ 4ZWK-BYF7] (comparing the various "Selected Country Summary" tables to demonstrate that poultry constitutes a high percentage of agricultural animals in both the United States and Brazil).

${ }^{169}$ See Poletto \& Hotzel, supra note 164 , at 28.

${ }^{170}$ See Gabriel Elizondo, Brazil Drought Dries Up Milk Production, AL JAZEERA (Feb. 28, 2013), http://www.aljazeera.com/indepth/features/2013/02/20132271178852954.html [http://perma. cc/Y29QFS46]; Keeping It Real, MEAT \& POULTRY (Apr. 24, 2009), http://www.meatpoultry. com/Writers/Other\%20Contributors/Keeping\%20it\%20real.aspx?cck=1 [http://perma.cc/AYP5-4BGG]. 
$\otimes$ JURIS POIESIS

See generally Carlos Steiger, Modern Beef Production in Brazil and Argentina, 21 CHOICES 105 (2006), http://www.choicesmagazine.org/2006-2/tilling/2006-212.pdf [http://perma. 
Brazil's live export industry — already massive—-has surged. ${ }^{171}$ Live export involves transporting living animals to other countries for slaughter. ${ }^{172} \mathrm{Bra}$-zil exports approximately 480,000 cattle per year, primarily to Venezuela and Lebanon. ${ }^{173}$ Though Brazil boasts of the quality of its "green" cattle, the exportation process involves a long journey, often by truck and boat during which the animals are crammed into very small spaces, often without access to food or water. ${ }^{174}$ All steps of the process create traumatic, stressful, and unhealthy conditions that lead to terrible suffering and high mortality. ${ }^{175}$ As a result, and even assuming the animals were well-treated prior to beginning their final journey, the next phase of their short lives is well beyond what most would consider humane or even endurable. ${ }^{176}$ In sum, the protections afforded to agricultural animals in Brazil are insufficient, just as they are in the United States. ${ }^{177}$ And, as the industry continues to grow, the number of animals and quantum of mistreatment will necessarily grow, as well. ${ }^{178}$

\section{Exempting Agricultural Animals from Anti-Cruelty Protection Exacerbates the Problem}

The foregoing discussion identified laws and practices currently in place that address animal welfare in both the United States and Brazil. ${ }^{179}$ While the United States provides agricultural animals with fewer statutory

cc/D745 -2JME] (explaining the growth of Brazil's beef production while also acknowledging the need for improvement therein).

${ }^{171}$ Pontifícia Universidade Católica do Rio de Janeiro, EXPortaÇão Brasileira de BovinOS Vivos 45 (n.d.), http://www.maxwell.vrac.puc-rio.br/18154/18154_5.PDF [http://perma. cc/2878-85V4] (noting that in the last seven years, Brazil has become the third largest exporter of live beef in the world); see Ass'N of BRAZ. BeEF EXPS., Structure of Brazilian BeEF Chain (2010), www.abiec.com.br/download/Brazilian\%20Beef\%20Chain.pdf [http://perma.cc/NN9W J8SM]; Cassuto \& Saville, supra note 8, at 200-01.

${ }^{172}$ See Let's End the Cruelty of Live Export, WORLD ANIMAL PROT., http://www.world animalprotection.org.au/our-work/animals-in-farming/live-export [http://perma.cc/M44M-23LY].

${ }^{173}$ See AssosiaÇão Brasileira dos EXPORTADORES DE Gado, VANTAGENS DA EXPORTAÇão DE BovinOS VIVOS NO BRASIL 45 (2013), http://www.abegbrasil.org/Scot/revista4/.

${ }^{174}$ See Phil Brooke, Live Animal Exports, in The Global Guide to Animal Protection 104, 104-06 (Andrew Linzey ed., 2014); Sustainability: History, BRAZILIAN BeEF, http://www. brazilianbeef.org.br/texto.asp?id=3 [http://perma.cc/U5XF-4GFX] (noting that the term "Green" cattle describes sustainable cattle production that does not degrade or harm the surrounding natural environment).

${ }^{175}$ See Brooke, supra note 174.

${ }^{176}$ See id.

${ }^{177}$ See supra notes $41-176$ and accompanying text.

${ }^{178}$ See Elizabeth Bennett, Animal Agriculture Laws on the Chopping Block: Comparing Unit-ed States and Brazil, 31 PACE ENVTL. L. REV. 531, 543-44 (2014) (describing how farming in Brazil is becoming more concentrated, worsening the conditions for farmed animals and augment-ing mass production techniques).

${ }^{179}$ See supra notes $41-176$ and accompanying text. 
and regulatory protections, widespread mistreatment is the norm in both countries. ${ }^{180}$ Unfortunately, in both the United States and Brazil, the reach of cruelty protections is quite narrow, effectively applying only to house pets. ${ }^{181}$ Because pets comprise a miniscule percentage of animals in human society, cruelty laws as written and applied offer very little animal protection at all. ${ }^{182}$ Indeed, as David Wolfson has observed, the number of animals protected by law as compared to those who have no protection at all is so small that animal law as such effectively does not exist. ${ }^{183}$ This section ex-amines the animal cruelty that arises from the "common" practices of indus-trial farms in both nations despite their respective legal and regulatory re-gimes and alleged commitment to animal welfare. ${ }^{184}$

Most agricultural animals:

$[\mathrm{N}]$ ever experience sunshine, grass, trees, fresh air, unfettered movement, sex, or many other things that make up most of what we think of as the ordinary pattern of life on earth. They are cas-trated without anesthesia, on occasion deliberately starved, live in conditions of extreme and unrelieved crowding, and suffer physi-cal deformities as a result of genetic manipulation. ${ }^{185}$

For example, Smithfield Foods, the largest pork producer in the world, produces six billion pounds of pig meat annually by confining the animals "by the hundreds or thousands in warehouse-like barns, in rows of wall-to-wall pens ... . Forty fully grown 250-pound male hogs often occupy a pen the size of a tiny apartment . . . . There is no sunlight, straw, fresh air, or earth." 186 Though Smithfield Foods committed to a phase-out program for gestation crates in 2009 and 2011, as of January 2014 the crates remained in

${ }^{180}$ See supra notes $41-176$ and accompanying text.

${ }^{181}$ See Cassuto \& Saville, supra note 8, at 195, 203; Farmed Animals and the Law, ANIMAL LEGAL DEF. FUND, http://aldf.org/resources/advocating-for-animals/farmed-animals-and-the-law/ [perma.cc/CPV6-Q38K] (last updated Mar. 23, 2015).

${ }^{182}$ Compare Pet Statistics, ASPCA, https://www.aspca.org/animal-homelessness/shelterintake-and-surrender/pet-statistics [perma.cc/RT6W-6S9C] (estimating that U.S. families currently own approximately 70-80 million pet dogs and 74-96 million pet cats), with Farm Animal Statistics: Slaughter Totals, supra note 3 (estimating that 9.1 billion farm animals were slaughtered in the United States in 2014 alone).

${ }^{183}$ See Wolfson, supra note 2 , at 124 .

${ }^{184}$ See infra notes $185-212$ and accompanying text.

185 Anastasia S. Stathopoulos, Note, You Are What Your Food Eats: How Regulation of Factory Farm Conditions Could Improve Human Health and Animal Welfare Alike, 13 N.Y.U. J. LEGIS. \& PUB. POL'Y 407, 411 (2010) (citing Wolfson \& Sullivan, supra note 6). 

America's Top Pork Producer, Rolling STONE (Dec. 14, 2006), http://www.rollingstone.com/culture/news/boss-hog-the-dark-side-of-americas-top-pork-producer20061214 [http://perma.cc/9DX3-3Y7Q]. 
use in almost half of the company's facilities and in many of the independent facilities with which Smithfield contracts for pork. ${ }^{187}$

Gestation crates are cages that confine sows to a space so small that they cannot even turn around. ${ }^{188}$ The pigs languish in these crates for years. ${ }^{189}$ In addition to the obvious and ongoing discomfort they create, gestation crates cause an "elevated risk of urinary tract infections, weakened bones, lameness, behavioral restriction, and stereotypies." 190 Gestation crates are common in both Brazil and the United States, and are but one of countless examples of the mistreatment that forms the norm for billions of animals. ${ }^{191}$

Confinement practices often result in animals getting trampled and starved, as well as causing lameness, leg and joint disorders, emotional distress, and other health problems. ${ }^{192}$ In the egg industry, male chicks are killed shortly after they are hatched (males add no value to the egg production process). ${ }^{193}$ Females have their beaks cut off without anesthetic before getting confined to tiny battery cages where they endure unremitting discomfort until becoming "spent" (unable to produce). ${ }^{194}$ They are then killed,

${ }^{187}$ See Clare Leschin-Hoar, Pork Farmers to Let Pregnant Pigs Out of Confinement Crates, TAKEPART (Jan. 9, 2014), http://www.takepart.com/article/2014/01/09/beginning-end-gestationcrates [http://perma.cc/CT27-722J]; Smithfield Foods Recommits to 2017 Phase-Out of Gestation Crates, HUMANE SOC'Y OF THE U.S. (Dec. 8, 2011), http://www.humanesociety.org/news/press_ releases/2011/12/smithfield_foods_recommits_12082011.html.

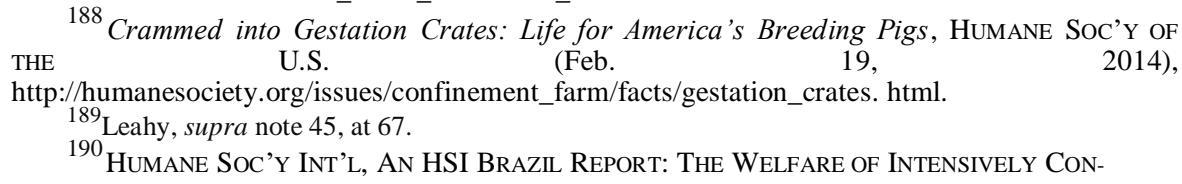
Fined ANIMALS IN BATTERy CAGES, GeSTATION CRATES, AND Veal CRATES 4 (n.d.) [hereinafter HSI BRAZIL R EPORT], http://www.hsi.org/assets/pdfs/welfare-of-intensively-confined-animalsbrazil-sept-08.pdf [http://perma.cc/K2XK-9X3C].

${ }^{191}$ See WORld SOC'y For the Prot. OF ANimals, Alternativas Práticas á PeCuÁria INDUSTRIAL NA AMERICA LATINA 4-5 (2010), http://issuu.com/wspa_brasil/docs/alternativas_ praticas_a_pecuaria_industrial/9; A Closer Look at Animals on Factory Farms, ASPCA, https:// www.aspca.org/animal-cruelty/factory-farms/animals-factory-farms [perma.cc/9HGK-NY2V] (de-scribing the agricultural norms for animal treatment throughout the beef cattle, dairy cattle, and veal industries in the United States); Humane Society International and Partners Deliver Petition Asking for Farm Animal Welfare Legislation, Humane Soc'y INT'L (Mar. 21, 2012), http://www. hsi.org/news/press_releases/2012/03/petition_032112.html (stating that in Brazil, "The majority of breeding sows (female pigs) are confined in individual metal gestation crates for nearly their entire lives, unable to even turn around").

${ }^{192}$ Stathopoulos, supra note 185 , at 411-12.

${ }^{193}$ See Sheila Rodriguez, The Morally Informed Consumer: Examining Animal Welfare Claims on Egg Labels, 30 Temp. J. ScI. TeCh. \& ENVtL. L. 51, 57 (2011).

${ }^{194}$ See United Egg Producers, United Egg Producers Animal Husbandry Guidelines

8 (2010), http://www.unitedegg.org/information/pdf/UEP_2010_Animal_Welfare_Guidelines.pdf [http://perma.cc/3CVP-FADV] (explaining that the purpose of beak trimming is to prevent cannibal-ism, pecking, feather pulling, and fighting amongst birds, but that it causes difficulty eating and 
often so carelessly that their deaths are slow and gruesome. ${ }^{195}$ Within the United States, 95-98\% of eggs come from hens raised in these wire cages too small for the hens even to spread their wings. ${ }^{196}$

In Brazil, "More than 90 percent of eggs are produced by birds who spend almost their entire lives confined in small battery cages in which each hen is given less space than a single sheet of letter-sized paper." ${ }^{197}$ These cages prevent birds from nesting, dust-bathing, perching, scratching, freely walking, and a whole host of other natural behaviors."198 Battery cages are stacked by the hundreds and thousands, and, in addition to causing the physical suffering mentioned above, they create psychological stresses that lead to cannibalism, emotional distress, and death. ${ }^{199}$

Even when cruel practices are exposed and publicized, it causes little change in the animals' treatment. ${ }^{200}$ The veal industry, for example, has received a great deal of attention, but the confinement practices that caused the public outcry remain widespread. ${ }^{201}$ Veal calves are typically chained by their necks in stalls so small that they can barely move for their entire six-teen-week lives. ${ }^{202}$ They are usually kept in the dark, and fed a nutrientdeficient diet to keep them anemic. ${ }^{203}$ The resulting iron-deficiency means

drinking, stress, and chronic and acute pain); Bruce Friedrich, The Cruelest of All Factory Farm Products: Eggs from Caged Hens, HufFPost Green: The Blog (Mar. 16, 2013), http://www. huffingtonpost.com/bruce-friedrich/eggs-from-caged-hens_b_2458525.html

[http://perma.cc/2PXT-4SSP] ("Battery cages are small wire cages where about 95 percent of laying hens spend their entire lives; each hen is given about 67-76 square inches of space.").

${ }^{195}$ Leahy, supra note 45 , at 65-66.

196 Id.

${ }_{197}^{196}$ Id. Humane Society International
Welfare Legislation, supra note 191.

${ }^{198}$ HSI BRAZIL REPORT, supra note 190, at 2.

${ }^{199} I d$; SARA SHIELDS \& IAN J.H. DUNCAN, HUMANE SOC'Y OF THE U.S., AN HSUS REPORT: A

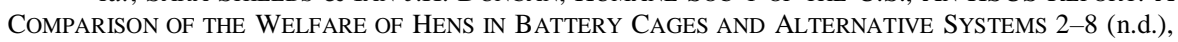
http://www.humanesociety.org/assets/pdfs/farm/hsus-a-comparison-of-the-welfare-of-hens-in-batterycages-and-alternative-systems.pdf [http://perma.cc/L8KH-QZJH].

${ }^{200}$ See Lauren Pack, Animal Cruelty a Problem Despite Increased Attention, JouRNAL-NEws (Oct. 19, 2013, 9:00 AM), http://www.journal-news.com/news/news/animal-cruelty-a-problem-despiteincreased-attenti/nbRq7/ [http://perma.cc/TB9H-G4RQ] (describing increase in animal cruelty cases for mistreatment of companion animals, despite increased awareness regarding the animal cruelty issue); Veal Crates: Unnecessary and Cruel, HUMANE SOC'Y OF THE U.S. (Feb. 22, 2013), http://www.humanesociety.org/issues/confinement_farm/facts/veal.html.

${ }^{201}$ See, e.g., Paul Gould, Cruel, Yes, but Very Tasty, Fin. Times (June 2006), http://www.ft. com/intl/cms/s/0/e83f62b4-f819-11da-9481-0000779e2340.html\#axzz3wag09w72 (describing how sow gestation crates persist despite public opposition); Veal Crates: Unnecessary and Cruel, su-pra note 200 (describing how inhumane practices in the veal industry persist despite "almost uni-versal public opposition").

${ }^{202}$ See Leahy, supra note 45, at 68-69.

${ }^{203} I d$. 
that the calves' flesh has the pale color that consumers have traditionally preferred. 204 "Suckling" pigs endure a similarly short and miserable life. ${ }^{205}$

The list of cruel practices continues and has been well documented elsewhere. ${ }^{206}$ In the pork industry, piglet's tails are cut off, their ears are notched, and male pigs are castrated, all without anesthetic. ${ }^{207}$ Beef cattle must endure (among other things) dehorning, castration, and branding, also without any anesthetic. ${ }^{208}$ Because slaughter methods are either underregulated or unenforced in both countries, common methods of slaughter also cause significant suffering. ${ }^{209}$ The animals are often inadequately stunned and thus conscious as they get boiled and skinned alive. ${ }^{210}$

Clearly, inhumane treatment is commonplace in both nations and shows no sign of abating. ${ }^{211}$ The next section offers an explanation describing the underlying forces that allow for and support common practices of agricultural animal mistreatment. ${ }^{212}$

\section{Lack of Protection and Cruelty to Agricultural Animals Have Become Entrenched Within the United States AND BRAZIL}

\section{A. United States-Pressures and Political Tensions Leading to Lack of Protection Against Cruelty}

The agricultural lobby in the United States has historically wielded enormous power and influence on the legislative and regulatory processes, as well as on the imagination of the American public. ${ }^{213}$ Unfortunately, the reality of the agricultural industry has little in common with the popular imagination or the rhetoric of the political process. Within the agricultural industry animals are referred to as "'food-producing units,' 'protein harvesters,' 'converting machines,' 'crops,' 'grain-consuming animal units' (as

204 See Farm Animal Welfare: Cows, MSPCA-ANGELL, http://www.mspca.org/programs/ animal-protection-legislation/animal-welfare/farm-animal-welfare/factory-farming/cows/vealcalves-on-a-factory-farm.html [http://perma.cc/8772-8DJH].

${ }^{205}$ See Gould, supra note 201 (describing the life, death, and consumption of these animals, and defining suckling pigs as piglets that are taken from their mothers and killed for food when they are approximately three weeks old).

${ }^{206}$ See Leahy, supra note 45 , at 65-69.

${ }^{207}$ See id. at $65-66$.

${ }^{208} I d$. at $67-69$.

${ }^{209}$ See Bennett, supra note 178 , at 538-56.

${ }^{210}$ See Leahy, supra note 45, at 67-69; see also WORLD SOC'Y FOR THE PROT. OF ANIMALS, supra note 191.

${ }^{211}$ See supra notes $179-210$ and accompanying text.

${ }^{212}$ See infra notes $213-264$ and accompanying text. 
${ }^{213}$ DAVID N. CASSUTO, ANIMALS \& SOC'Y. INST., REVISTA DO CURSO DE DIREITO DA UNIVERSIDADE ESTACIO DE S. THE CAFO Hothouse: Climate CHANGE, INDUSTRIAL AGRICUlture AND THE LAW 16 (2010),
http://www.derechoanimal.info/images/pdf/ Cassuto-CAFO-Nothouse.pdf [http://perma.cc/35KW$8 \mathrm{~N} 3 \mathrm{Z}]$. 
defined by the United States Department of Agriculture) and 'biomachines." 214

The impact of these terms goes beyond the merely linguistic. It changes the way animals and their needs are perceived. ${ }^{215}$ One can scarcely imagine, for example, lobbying for stricter laws to protect a "protein harvester" or a "grain-consuming animal unit." ${ }^{216}$ Indeed, the costs involved in pre-serving the animals' well-being are viewed as balance sheet net negatives to be reduced whenever possible. ${ }^{217}$ Relegating animals to mere components of an industrial process derogates their sentience and renders their well-being an ancillary concern at best. ${ }^{218}$ At worst, the animals' basic needs are perceived as costs to be reduced, liabilities the significance of which gets measured in dollars rather than by quotient of suffering. ${ }^{219}$

Moreover, the U.S. government, prodded by the farm lobby, has created "a legally protected sphere whereby any act, if it is viewed as customary by the United States farming community, is determined not to be cruel." ${ }^{220}$ Dating back to the post-WWII era:

[T] he post- war economy allowed people to purchase more meat per capita, the percentage of Americans who were sustenance farmers dropped, and technological advances allowed industrial means to be applied to agricultural production, including inten-sive confinement, mechanized treatment, and the beginnings of genetic manipulation of animals to increase their meat, egg, and milk output. ${ }^{221}$

This economic climate fostered factory farming, and as industrial agriculture grew, the industry gained stronger political power and consumers be-came more accustomed to semantically obscuring their meat consumption by "labeling pig as pork bacon, or sausage; cow as beef or hamburger; sheep as mutton; calves as veal; and deer as venison."222 The animal itself

${ }^{214}$ Wolfson, supra note 2 , at 147.

${ }^{215} I d$. (describing how the words humans use help them "remain ignorant of the abuse of living creatures that lies behind the food we eat").

216 See id. (describing how humans "disguise the source of meat" so as not to be reminded where it comes from).

${ }^{217}$ See Bennett, supra note 178 , at 562 .

${ }^{218}$ Wolfson, supra note 2, at 147.

${ }^{219}$ See id. at 127 (discussing animals seen as economic goods, in relation to human benefit).

${ }^{220}$ Id. at 147.

${ }^{221}$ Leahy, supra note 45 , at 65. 

note 51, at 200 (noting that due to the pressure from the agricultural industry advocates, Congress omitted poultry in the final version of the Humane Methods of Slaughter Act). 
was no longer foremost in the vocabulary of consumption and as a result, lost primacy in the consciousness of the consumer, as well. ${ }^{223}$

The modern agricultural industry has enormous political power and uses the romantic rhetoric of the family farm to shield itself from regulation and critical scrutiny. ${ }^{224}$ Yet, the modern agricultural industry is completely different than the small family-run farms of eras past. ${ }^{225}$ Today, a few giant corporations dominate the industry. ${ }^{226}$ A 2012 study from the University of Missouri-Columbia found that "the four largest companies controlled 82 percent of the beef packing industry, 85 percent of soybean processing, 63 percent of pork packing, and 53 percent of broiler chicken processing." 227 As one commenter points out, "[A]gribusiness concentration works in many ways, all with same objective: to move income from farmers and rural economies to Wall Street." 228 So, even as the industry appropriates the culturally powerful rhetoric of the small farmer to lobby and advertise, its methods and policies actually drive small farmers out of business. ${ }^{229}$

In the United States, the industry's power is visible at every phase of the regulatory process. ${ }^{230}$ For example, the American Farm Bureau Federation successfully deterred Congress from passing a bill that would have required an eighteen-month delay before the merger of big agricultural com-panies. ${ }^{231}$ The bill would have also required the formation of a Commission to examine market power and concentration in the agricultural industry. 232

The federal government has supported agribusiness for decades through price support programs, mandatory generic advertising campaigns,

${ }^{223}$ See Cassuto \& Saville, supra note 8, at 195, 204; Wechsler, supra note 51, at 200.

${ }^{224}$ See CASsuto, supra note 213 , at 8.

${ }^{225}$ See id. at 7-8.

${ }^{226}$ See, e.g., Wolfson, supra note 2, at 145 (quoting Senator Metzenbaum as stating, "Twenty companies produce eighty percent of U.S. poultry. Four [of these] companies produce forty per-cent").

${ }^{227}$ FoOd \& WATER WATCh, THE ECONOMIC COST OF FOOD MONOPOLIES 4 (2012) https:// www.foodandwaterwatch.org/sites/default/files/Food\%20Monopolies\%20Report\%20Nov\%20201 2.pdf [perma.cc/F7UT-WGXE].

${ }^{228}$ Id. ("Large retailers now have so much buying power that they have considerable influence over which foods are available to the public, the methods in which the foods are produced and the prices paid to their suppliers.").

${ }^{229}$ See CAssuto, supra note 213, at 1-2; Food \& WATER WATch, supra note 227, at 4-5.

${ }^{230}$ See Steve Johnson, The Politics of Meat, FrONTLINE, http://www.pbs.org/wgbh/pages/ frontline/shows/meat/politics/ [http://perma.cc/J8H4-8M75] (detailing how the agricultural industry exerts substantial influence over the governmental decision-making process as it pertains to the industry).

${ }^{231}$ See Agribusiness Merger Moratorium and Antitrust Review Act of 1999, H.R. 3159, 106th Cong. at 9 (1999); A.V. Krebs, U.S. Senate Votes 71-27 to Reject Wellstone Agribusiness Merger Moratorium, Agribusiness EXAM’R (Nov. 23, 1999), http://www.thecalamityhowler.com/agbiz/ agex56.html [http://perma.cc/6F39-UQ95]. 
${ }^{232}$ See Wechsler, supra note 51 , at 190. 
the national school lunch program, and exemptions from environmental regulations. ${ }^{233}$ Federal policies also incentivize Confined Animal Feeding Operations ("CAFOs") through tax breaks and subsidies for building feedlots. ${ }^{234}$ Furthermore, as the Agricultural Act of 2014 ("Farm Bill") demonstrates, even as deficit and price support programs have come under increased scrutiny, support for the agricultural industry remains a priority. ${ }^{235}$ Under the Farm Bill, the industry continues to receive (among other benefits) subsidized crop insurance and subsidies for rice and peanut growers. $^{236}$

It barely merits mention that the law does not address animal welfare standards at all. 237

At the state level, statutory exemptions for "customary farming practices" that cause widespread animal suffering are common. ${ }^{238}$ Because "customary" is determined by the agricultural industry, which profits from the practices, the interest of the agricultural animal is unprotected and ignored. ${ }^{239}$ In the aggregate, state exemptions and a lack of federal protection have enabled the agricultural industry to determine for itself what protections should be afforded to the animals. Unsurprisingly, such protections are virtually nonexistent. ${ }^{240}$

${ }^{233}$ Ruhl, supra note 89 , at 331-33; Wechsler, supra note 51, at 183-84.

${ }^{234}$ See Wechsler, supra note 51, at 185.

${ }^{235}$ See David Orden \& Carl Zulauf, The Political Economy of the 2014 Farm Bill, AGRIC. \& APPLIED ECON. ASS'N, Jan. 4, 2015, at 1, 3-4, http://webcache.googleusercontent.com/search? q=cache:mD7nw727tYQJ:https://www.aeaweb.org/aea/2015conference/program/retrieve.php\%3F pdfid\%3D262+\&cd=1\&hl=en \&ct=clnk\&gl=us\&client=safari [https://perma.cc/FC4T-C77D]. See generally Agricultural Act of 2014, Pub. L. No. 113-79, 128 Stat. 649-1005 (codified as amended at scattered sections of 7 U.S.C.).

${ }^{236}$ See generally Agricultural Act of 2014, 128 Stat. 649-1005 (providing benefits to the agri-culture industry; Ron Nixon, Senate Passes Long-Stalled Farm Bill, with Clear Winners and Losers, N.Y. TIMES, (Feb. 4, 2014), http://www.nytimes.com/2014/02/05/us/politics/senatepasses-long-stalled-farm-bill.html?_r=0 [http://perma.cc/U9CE-UZ7X] (describing how the Farm Bill "created new subsidies for rice and peanut growers").

237 See generally Agricultural Act of 2014, 128 Stat. 649-1005 (demonstrating the government's great concern with supporting the agricultural industry while not demonstrating that same concern for animal welfare).

${ }^{238}$ See supra notes 179-212 and accompanying text.

${ }^{239}$ Wolfson, supra note 2 at 147. 
${ }^{240}$ See Matheny \& Leahy, supra note 5, at 326;

Wolfson, supra note 2, at 151; Wolfson \& Sullivan, supra note 6, at 210. 


\section{B. Brazil-Pressures and Political Tensions Leading to Lack of Protection Against Cruelty}

Brazil's agricultural lobby is similarly powerful as that of the United States, and its power continues to grow. ${ }^{241}$ Unlike the United States, the lobby in Brazil remains informal and difficult to monitor or track. ${ }^{242}$ Even as it has eschewed a formal organizational structure, the agribusiness lobby has gained an outsized voice on many legal, political, and economic decisions. ${ }^{243}$ This has led to widespread subsidies, which have further bolstered the industry and increased its influence in a repeating cycle of empowerment and enrichment. ${ }^{244}$ As the power and influence of the agricultural industry has grown, concern for animal well-being has decreased. ${ }^{245}$ Given the bottom-line focus of the industry and the fact that animals are viewed as fungible with low replacement costs, this trend reflects the industry's log-ic. ${ }^{246}$ With consumption of animal products continuing to increase, the means by which the industry meets the ballooning global demand will inevitably result in more harm to more animals. $^{247}$

${ }^{241}$ See Alastair Stewart, Agriculture Drags Along Brazilian Economy, DTN: ProgressIVE FARMER, (Sept. 24. 2013, 11:09 AM), http://www.dtnprogressivefarmer.com/dtnag/common/ Vlink.do?symbolicName $=/ \mathrm{ag} / \mathrm{b} \operatorname{logs} / \mathrm{template} 1 \&$ blogHandle $=$ southamerica\&blogEntryId $=8 \mathrm{a} 82 \mathrm{c} 0 \mathrm{bc}$ 3e43976e014150bb4a521e1e [http://perma.cc/6ZN3-KFPE].

${ }^{242}$ Compare Richard Briffault, The Anxiety of Influence: The Evolving Regulation of Lobby-ing, 13 ELECTION L.J. 160, 162, 165-66 (2014) (describing the regulations imposed upon lobby-ists in the United States), with Sobrevivência da Velha Bancada Ruralista é de 51,2\% [Survival of the Old Rural Caucus Is 51.2\%], INESC (Aug. 10, 2010), http://www.inesc.org.br/noticias/ noticias-doinesc/2010/outubro/bancada-ruralista-perdeu-45-9-dos-integrantes [http://perma.cc/ V2LW-DES3] (describing how the agriculture lobby in Brazil rarely acts in a coordinated man-ner).

${ }^{243}$ Rasheed Abou-Alsamh, Brazil's Agricultural Boom: Farmers Face Off Against Indians in Classic Conflict Pitting People Seeking Land Against People Growing Food, InT’L BuS. Times, (June 8, 2013, 10:26 AM), http://www.ibtimes.com/brazils-agricultural-boom-farmers-face-against-indiansclassic-conflict-pitting-people-seeking-land [http://perma.cc/N59A-A4JW].

${ }^{244}$ See Stewart, supra note 241.

245 See Humane Soc'y. InT'L, HSI Fact SheEt: The Impact of ANIMAL AgRiculture ON THE ENVIRONMENT AND Climate CHANGE IN BRAZIL 1 (n.d.) [hereinafter HSI FACT SHEET], http:// www.hsi.org/assets/pdfs/hsi-fa-white-papers/brazil_climate_change_factsheet.pdf [http://perma.cc/ BZ5F-2U9N].

${ }^{246}$ See Harwood D. Schaffer et Al., Pew COMm'n On Indus. Farm ANimal Prod., ECONOMics of Industrial FARM ANimal Production 31, 33 (n.d.), http://www.ncifap.org/ _images/212-6_pcifap_ecnmics_v5 _tc.pdf [http://perma.cc/7L85-LBRP] (exploring the costs of industrial farm animal production, and concluding that, "CAFOs appear to be efficient because they can externalize significant costs onto others and society at large").

${ }^{247}$ See Poletto \& Hotzel, supra note 164, at 24 ("According to a FAO report (2009), meat consumption in the developed countries is expected to increase by about 15 million tons over the 
20-year period (1995-2015) in contrast with 75 million tons forecasted in the developing world within the same time frame.”). 
Consumer backlash sometimes leads to reforms within the industry. ${ }^{248}$ Yet, when reforms lead to increased costs, there is a marked drop-off in the public's willingness to pressure the industry to change. ${ }^{249}$ Studies have shown that cost, rather than conscience, most often drives purchasing decisions. ${ }^{250}$

Brazil is home to large corporations that control a substantial portion of the agricultural market. ${ }^{251}$ This economic dominance allows these entities to exercise significant influence on policymaking. ${ }^{252}$ Also similar to the United States, Brazilian agricultural production has prospered at the expense of small farmers. ${ }^{253}$ As in other emerging economies, Brazil has consolidated production through vertical integration. ${ }^{254}$ In Brazil, four integrators supply $40 \%$ of broiler chickens. ${ }^{255}$ In the dairy industry, the number of milk producers fell by $23 \%$ between 2000 and 2002 while the volume of milk production stayed the same. ${ }^{256}$ In the state of Santa Catarina alone, "20,000 families left the countryside in 1998, many leaving pig and poultry production because they could not compete with the big corporations." 257 Similar trends are visible throughout the country, fueling the growth of in-dustrial agriculture and fortifying its impact on policymaking. ${ }^{258}$

Brazil's regulatory process also faces the threat of agency capture. ${ }^{259}$ As the largest meat exporter in the world, Brazil's cattle herd exceeds 250

${ }^{248} I d$. at $23,27$.

${ }^{249} I d$. at 27.

${ }^{250}$ Id. at 23; see Terence J. Centner, Limitations on the Confinement of Food Animals in the United States, 23 J. AgRic. \& Envtl. Ethics 469, 470 (2010); Athanasios Krystaliss et al., Attitudes of European Citizens Towards Pig Production Systems, 126 Livestock SCI. 46, 47 (2009); Jayson L. Lusk \& F. Bailey Norwood, Public Opinion and the Ethics and Governance of Farm Animal Welfare, 233 J. AM. Vet. Med. Ass'N 1, 1-6 (2008).

${ }^{251}$ See HSI FACT SHEET, supra note 245, at 1.

252 See id; Análises e Infográficos Quem é Quem no Mundo Rural, REPUBLICA DOS RURALISTAS, http://www.republicadosruralistas.com.br/analises/3 [http://perma.cc/J88A-WRVG]; Paulo Prada, Fateful Harvest: Why Brazil Has a Big Appetite for Risky Pesticides, REUTERS (Apr. 2,

2015,2:50 PM), http://www.reuters.com/investigates/special-report/brazil-pesticides/

[http://perma.cc/RBM4-2GB4].

${ }^{253}$ See HSI FACT SHEET, supra note 245 , at 1.

${ }^{254}$ See id.

${ }^{255} I d$.

${ }^{256}$ Id.; see Josh Marks, Regulating Agricultural Pollution in Georgia: Recent Trends and the Debate Over Integrator Liability, 18 GA. ST. U. L. REv. 1031, 1033 (2002) (defining integrators as "corporate owners of . . . animals").

${ }^{257}$ JANice COX, World SOC'y FOR THE Prot. OF ANimAls, INDUSTRIAl ANimal AgRiculTURE: PART OF THE POVERTY PROBLEM 17 (2007), http://www.worldanimalprotection.ca/sites/ default/files/ca_-_en_files/wspa_poverty_report_tcm22-3744.pdf [http://perma.cc/G42Y-HVJU].

${ }^{258}$ See HSI FACT SHEET, supra note 245 , at 4.

${ }^{259}$ See infra notes 260-264 and accompanying text. 
million animals. ${ }^{260}$ Nonetheless, and despite its recent emergence as a glob-al economic power, Brazil remains in many respects a developing nation. ${ }^{261}$ Its economy is fragile and its comparatively strong animal welfare standards exist in tension with its economic impulsion to generate the maximum amount of animal products at the lowest possible cost. ${ }^{262}$ Additionally, Per-manent Technical Commission on Animal Welfare, the agency assigned to promote animal welfare within the agricultural industry, focuses instead on management strategies aimed at yielding the highest production and best quality of meat. ${ }^{263}$ Animal welfare is a secondary concern at best. ${ }^{264}$

\section{Solutions to Promoting the Well-Being of ANimals WITHIN THE AGRICULTURAL INDUSTRY}

The raw political power of the agricultural industry coupled with undiscerning consumer demand has created a regulatory vacuum in the United States, as well as widespread exemptions and lack of enforcement in the United States and Brazil. ${ }^{265}$ Both countries allow an industry for which min-imizing animal welfare maximizes profit, to determine the standards and methods for the animals' treatment. ${ }^{266}$ Brazil has acknowledged the need to change this model but neither country has efficiently curbed rampant abuses

${ }^{260}$ HSI FACT SHEET, supra note 245, at 1; see Brazilian Market, MinERVA FoOdS, $\mathrm{http}: / /$ ri.minervafoods.com/minerva2012/web/conteudo_en.asp?idioma $=1 \&$ conta $=44 \&$ tipo $=40424$ [http://perma.cc/LB53-RZJA] (last updated Jan. 21, 2014) (citing to data published by the United States Department of Agriculture in May 2013).

${ }^{261}$ See Brazil: Overview, WORLD BANK, http://www.worldbank.org/en/country/brazil/overview [https://perma.cc/76BM-3GWX] (indicating through statistics and discussion that while there was significant economic growth, many development indicators still demonstrate data of a developing country). As of 2014, Brazil is the seventh largest economy in the world. WORLD BANK, GROSS DOMESTIC PRODUCT 2014, at 1 (2015), http://databank.worldbank.org/data/download/GDP.pdf [http://perma.cc/DZP3-KBP3]. The recession that gripped the country in 2015 bears further wit-ness to the fragility of its economy. See Brazil's Economy Enters Recession, BBC NEws (Aug. 28, 2015), http://www.bbc.com/news/business-34088144 [perma.cc/MC3E-X24C].

${ }^{262}$ See VAPNEK \& ChAPMAN, supra note 140, at 3; Protests in Brazil: Taking to the Streets, ECONOMIST (June 22, 2013), http://www.economist.com/news/americas/21579857-bubbling-angerabout-high-prices-corruption-and-poor-public-services-boils-over [http://perma.cc/CAN8-Q2NR] (discussing how a nine cent rise in bus fares sparked one of the biggest street demonstrations in Brazil since 1992); see also Paolo Winterstein, Brazil Real Has Further to Fall, WALL ST. J., (Aug. 16, 2013, 4:26 PM), http://www.wsj.com/articles/SB1000142412788732345510457901 7022209075440 (discussing the steady decline in value of Brazilian currency and how easily Bra-zil's economy is affected by declines in the U.S. economy).

${ }^{263}$ See generally Ministry OF AGRic., Livestock \& FoOd SupPly, STRATEGiC Plan (2010), http://www.agricultura.gov.br/arq_editor/file/4039_strategic_plan_f.pdf [http://perma.cc/ D4DR-KKZA] (outlining Brazil's agricultural management priorities).

${ }^{264}$ Ministry OF AGRIC., Livestock \& FOOD SuPPLY, supra note 162.

${ }^{265}$ See supra notes 213-264 and accompanying text.

${ }^{266}$ See supra notes $213-264$ and accompanying text. 
within the industry. ${ }^{267}$ Effective regulation and proper incentives to obey, coupled with additional incentives to monitor, form the baseline for a regulatory regime that is sensitive to animal welfare. ${ }^{268}$

We suggest that the best way to create such a regime is through the formation of an independent regulatory agency devoted solely to animal welfare in both the United States and Brazil. Such an agency would owe no allegiance to the agricultural industry and would therefore be less vulnerable to agency capture. The next sections describe how such an Animal Welfare Agency would operate in the respective countries.

\section{A. Animal Welfare Agency in the United States}

An independent agency unaffiliated with or nested within any existing agency or cabinet-level department would alleviate the pressure from the agricultural lobby and the entrenchment of industry norms and end the consistent privileging of economics over animal welfare. Independent agencies are not located directly within an executive department or within the executive branch. They are therefore insulated from political interests and pressures that might otherwise influence their actions. ${ }^{269}$ These impartial agencies are "charged with the enforcement of no policy except the policy of the law." 270 This impartiality and focused implementation of the law provides a useful foundation for addressing the systemic challenges of animal wel-fare. ${ }^{271}$ The next sections describe how this agency, which we are tentatively naming the Animal Welfare Agency ("AWA"), might look if created in the United States. ${ }^{272}$

\section{Structure to Ensure Independence}

Every agency is created by an enabling statute, which establishes the agency's structure and purpose and delegates the necessary authority to effectuate that purpose. ${ }^{273}$ The enabling statute also includes the necessary

${ }^{267}$ See supra notes 213-264 and accompanying text.

${ }^{268}$ See infra notes 273-326 and accompanying text.

${ }^{269}$ Marshall J. Breger \& Gary J. Edles, Established by Practice: The Theory and Operation of Independent Federal Agencies, 52 ADMIN. L. REV. 1111, 1113 (2000); see also U.S. Gov'T PRINTING OFFICE, INDEPENDENT AGENCIES AND GOVERNMENT CORPORATIONS (n.d.), http://www. gpo.gov/fdsys/pkg/GPO-PLUMBOOK-2012/pdf/GPO-PLUMBOOK-2012-9.pdf [http://perma.cc/ LT7K-6C9V] (listing the following examples of independent agencies: Consumer Product Safety Commission, Environmental Protection Agency, National Transportation Safety Board, Nuclear Regulatory Commission).

${ }^{270}$ Breger \& Edles, supra note 269, at 1113.

${ }^{271}$ See supra notes 213-264 and accompanying text (discussing challenges of current laws).

${ }^{272}$ See infra notes 273-294 and accompanying text.

2734 Charles H. Koch, JR., Administrative LaW AND Practice $§ 11: 13$ (3d ed. 2015). 
information to establish the institutional structure and level of independence of the agency. ${ }^{274}$ The Animal Welfare Agency would require a strong ena-bling statute in order to effectively shift authority that has become well-entrenched elsewhere and to clearly establish the agency's independence. ${ }^{275}$

Traditionally, independent agencies are structured as multi-member commissions with "for cause" removal protection. ${ }^{276}$

"For cause" removal is the most salient feature of American independent agencies, and is integral to the ability to function without presidential oversight and pressure. ${ }^{277}$

"For cause" means that the agency head (or any Commissioner) cannot be removed at will. ${ }^{278}$

That means that officials may only be removed for "inefficiency, neglect of duty, or malfeasance in office." 279

Because independence

is vital to the AWA, for cause removal must be part of the AWA's enabling act. $^{280}$

Organizations structured in this manner "tend[] toward accommodation of diverse or extreme views through the compromise inherent in the process of collegial decision-making," thus leading to less politically biased results. ${ }^{281}$ Therefore, the enabling statute for the AWA should provide for an agency led by a Commission of five to seven members, rather than a Director or Administrator. A Commission can better resist political pressures and can make unpopular choices without fear of reprisal or backlash. ${ }^{282}$

${ }^{274}$ See, for example, the Federal Food, Drug and Cosmetic Act, which provides authority to the Food and Drug Administration. 21 U.S.C. $\$$ 301-399f (2012).

${ }^{275}$ See supra notes 87-89 and accompanying text (discussing the self-regulation of the agriculture industry).

${ }^{276}$ Rachel E. Barkow, Insulating Agencies: Avoiding Capture Through Institutional Design, 89 TEX. L. REV. 15, 16-17 (2010).

${ }^{277}$ See Mistretta v. United States, 488 U.S. 361, 410-11 (1989) (“[L]imitation on the President's removal power . . . is specifically crafted to prevent the President from exercising 'coercive influence' over independent agencies."); see also Barkow, supra note 276, at 29 ("A removal restriction undoubtedly gives an agency head greater confidence to challenge Presidential pressure.").

${ }^{278}$ See Barkow, supra note 276, at 27 ("Whether an agency head should be removable at will or serve a term of years and be removable only for cause before his or her term expires is, as noted, the insulation design feature that is most often used to demarcate an agency as "independent."').

${ }^{279}$ See 15 U.S.C. $\$ \S 41,2053$ (2012); 42 U.S.C. $\$ \S 5841(e), 7171(b)(1)$ (2012) (Nuclear Regulatory Commission and Federal Energy Regulatory Commission, respectively). 
${ }^{281}$ Breger \& Edles, supra note 269, at 1113.

${ }^{280}$ See supra note 277 and accompanying text.

${ }^{282}$ See, e.g., 42 U.S.C. $\$ 7171($ b)(1). Section 7171(b)(1) offers an example of an independent agency (Federal Energy Regulatory Commission) whose enabling act includes all of the previous-ly discussed essential, independent structural elements. $I d$. The enabling act states:

The Commission shall be composed of five members appointed by the President, by and with the advice and consent of the Senate. One of the members shall be designated by the President as Chairman. Members shall hold office for a term of 5 years 
Another important way to maintain agency independence and protect against infiltration of presidential and private interests would involve including a provision limiting the number of Commissioners affiliated with the President's political party. ${ }^{283}$ Such a provision would ensure fair political distribution, diminish partisan imbalance, and prevent skewed policy objectives. For example, a Commission of five might include at least two Commissioners that are members of a political party other than the President's. A Commission of seven would have at least three members of a different party than the President. Commissioners must also have terms that are longer than the President's so as to ensure continuity and agency stability, and also to protect against the President appointing the entire Commission and thus controlling the agency's allegiance. ${ }^{284}$ Therefore, the AWA's Commissioners should have six-year staggered terms. This would ensure that no one President dictates the AWA's policy aims. It would also facilitate the seamless accumulation of expertise. ${ }^{285}$

\section{Authority to Ensure Animal Welfare}

In addition to providing an independent structure, the AWA's enabling statute must pronounce with clarity the purpose and authority vested in the agency. The AWA's mission should be the protection of all animals from cruelty - including and indeed especially agricultural animals - from birth until death. ${ }^{286}$ The AWA must have the authority to regulate and ensure the proper treatment and conditions of animals when they are young, as they mature, during transport, and up to and during slaughter. ${ }^{287}$ Unlike Brazil,

and may be removed by the President only for inefficiency, neglect of duty, or malfeasance in office. Not more than three members of the Commission shall be members of the same political party. Any Commissioner appointed to fill a vacancy occurring prior to the expiration of the term for which his predecessor was appointed shall be appointed only for the remainder of such term.

Id. (emphasis added).

${ }^{283}$ See Barkow, supra note 276 , at 37-40.

${ }^{284}$ Id. at 25 .

${ }^{285}$ See id. at 29 (citing S. REP. No. 63-597, at 10-11 (1914) for the proposition that sevenyear terms of Federal Trade Commission Commissioners would "give them an opportunity to acquire the expertness in dealing with these special questions concerning industry that comes from experience").

${ }^{286}$ Factory Farms, ASPCA, https://www.aspca.org/animal-cruelty/factory-farms [perma.cc/ A3D9-LRF3] (noting that agricultural animals represent $99 \%$ of animals affected by humans).

${ }^{287}$ Some would argue - with reason-that any welfare regime that allows and enables the slaughter of animals is inherently flawed. See Rodriguez, supra note 193, at 58-59. However, we are not here arguing for animal slaughter. We are simply stating that if there is to be an agricultural regime wherein animals are raised and killed, then that regime should be regulated to make the animals' lives as comfortable and cruelty-free as possible. 


\section{JURIS POIESIS

the United States does not have a constitutional provision to guide the agency's mandate. ${ }^{288}$ And, as previously discussed, the United States has a woe-fully deficient regulatory regime that will require a number of statutory fix-es. ${ }^{289}$ Any new laws seeking to protect agricultural animals will almost certainly fail if they fall under the regulatory aegis of an agency that is overtaxed with respect to its resources and guided by a mission that conflicts with animal welfare. ${ }^{290}$

One of the principal challenges facing the creation of the AWA lies with the fact that the enabling statute must also take the form of a reorganization statute. In other words, all existing statutory authority for animal welfare must be re-delegated from existing agencies to the AWA. ${ }^{291}$ This would involve shifting regulatory authority mainly from the Department of Agriculture. ${ }^{292}$ Statutes that implicate animal welfare likely will require amendment or a comprehensive reorganization. ${ }^{293}$ This reorganization would be onerous at any time, but the current political climate, rife as it is with antagonism, mis-trust, and gridlock, makes it harder still.

Another significant challenge exists with respect to preemption of state laws. ${ }^{294}$ Large agricultural interests will seek guarantees that complying with federal regulations will excuse them from having to comply with the many and varied state laws. Permitting preemption would, in the authors' opinion, be a significant mistake as states may wish to lead on animal protection issues by enacting laws and regulations more progressive than those passed at the federal level.

\section{B. An Animal Welfare Agency in Brazil}

Over the past twenty years, Brazil has developed its regulatory sector to include numerous independent agencies that focus on everything from

${ }^{288}$ See supra notes $146-178$ and accompanying text (noting that Brazil's regulations pertain-ing to animals used in agriculture conform to European Union standards, which are more rigorous than those of the United States).

${ }^{289}$ See supra notes 41-122 and accompanying text (demonstrating that authority for oversee-ing that regime, such as it is, should transfer to the AWA, as well).

${ }^{290}$ See Barkow, supra note 276, at 21-24 (discussing potential problems with agency capture).

${ }^{291}$ Animal Welfare Act of 1970, 7 U.S.C. $\$ \S 2131-2159$ (2012). For example, the Depart-ment of Agriculture's Animal and Plant Health Inspection Service would no longer be responsible for regulating animal welfare. $I d$.

292 Id.

293 Id.

${ }^{294}$ See, e.g., Kerr v. Kimmell, 740 F. Supp. 1525, 1529-30 (D. Kan. 1990) (discussing a relat-ed issue of whether state law was preempted by the Animal Welfare Act). 
water allocation to electricity. ${ }^{295}$ Given the proliferation of independent agencies and the presence of the requisite political will, an Animal Welfare Agency could also emerge. The Brazilian Animal Welfare Agency ("AWA") should be an independent agency because independent agencies can insulate themselves from executive and political influence. ${ }^{296}$ In the sections that follow, we describe the institutional structure, delegated authority, and responsibilities that the AWA would be assigned. ${ }^{297}$

\section{Structure to Ensure Independence}

Like the United States, Brazilian law requires an enabling statute to create an independent agency. ${ }^{298}$ This statute creates the agency, outlines its structure, and delegates the necessary authority for it to function. ${ }^{299}$ The structural details found in the enabling act define the type of agency and its degree of independence. In Brazil, the main factors that establish an agency as independent include the selection method of agency officials, the type of leadership, the term length of officials, the removal procedure for officials, and the agency's financial independence. ${ }^{300}$

The AWA's enabling statute must ensure that the agency's structure accounts for and incorporates each of these factors, to avoid the political influence of the agricultural lobby and the primacy of political and economic interests. ${ }^{301}$ To do this, the statute must ensure that the Agency's head officers are appointed by the President and confirmed by the Senate. ${ }^{302}$ Senate confirmation checks the President's ability to simply appoint individuals

${ }^{295}$ See Mariana Mota Prado, The Challenges and Risks of Creating Independent Regulatory Agencies: A Cautionary Tale from Brazil, 41 VAND. J. TRANSNAT'L L. 435, $443-47$ (2008).

${ }^{296}$ See Constituição Federal [C.F.] [Constitution] art. 225 (Braz.).

${ }^{297}$ See infra notes $298-326$ and accompanying text.

${ }^{298}$ See, e.g., Medida Provisória No. 2.228-1, de 6 de Setembro de 2001, DiÁRIO OficIAL DA UNIÃo [D.O.U.] de 10.09.2001 (Braz.) (establishing the Agência Nacional do Cinema); Lei No. 10.233, de 5 de Junho de 2001, DiÁRIO Oficial DA União [D.O.U.] de 06.06.2001 (Braz.) (establishing Agência Nacional de Transportes Aquaviários and Agência Nacional de Transportes Terrestres); Lei No. 9.961, de 28 de Janeiro de 2000, DiáRIo OfiCIAL DA União [D.O.U.] de 28.01.2000 (Braz.) (establishing Agência Nacional de Saúde Suplementar); Lei No. 9.782, de 26 de Janeiro de 1999, Diário Oficial DA União [D.O.U.] de 27.01 .1999 (Braz.) (establishing Agência Nacional de Vigilância Sanitária); Lei No. 9.478, de 6 de Agosto de 1997, Diário OfiCIAL DA UNIÃo [D.O.U.] de 07.08.1997 (Braz.) (establishing Agência Nacional do Petróleo); Lei No. 9.472, de 16 de Julho de 1997, DiÁRIO OficIAL DA União [D.O.U.] de 17.07.1997 (Braz.) (establishing Agência Nacional de Telecomunicações); Lei No. 9.427, de 26 de Dezembro de 1996, Diário Oficial da União [D.O.U.] de 27.12.1996 (Braz.) (establishing Agência Nacional de Energia Elétrica).

\footnotetext{
${ }^{299}$ See supra notes $285-296$ and accompanying text.

${ }^{300}$ See Prado, supra note 295, at 435; supra notes 270-290 and accompanying text.

${ }^{301}$ See supra notes 270-290 and accompanying text.

${ }^{302}$ Prado, supra note 295 , at 478,478 n.234.
} 
who echo a particular political viewpoint or agenda. ${ }^{303}$ This procedure is already commonplace for independent agencies in Brazil. ${ }^{304}$ As in the United States, a Commission made up of five to seven members provides for greater independence because, unlike a single Director or Minister, the President is less likely to convince all Commissioners to pursue a specific goal or agenda. ${ }^{305}$

In addition to mandating the commission structure, the enabling statute should also prevent the appointment of all Commissioners from the same party. Partisan balance is more challenging in Brazil than in the United States because Brazil has a multi-party system. ${ }^{306}$ With so many parties rep-resented in the federal government, it would be difficult to ensure that all are represented on a panel of five to seven Commissioners. Therefore, the best option may involve requiring that no more than two Commissioners be from the President's party with the rest coming from various other factions. Furthermore, given the strong agricultural industry forces, Commissioners should not have business or economic interests related to the work or business undertaken by the AWA. ${ }^{307}$ This categorical bar would include an exception for veterinarians and those engaged in nonprofit work that clearly focuses on animal welfare.

The terms of the Commissioners should be staggered and exceed four years (the presidential term length). ${ }^{308}$ This way, no single President can control the agency and its policies. And, because Commissioners' terms outlive the presidential term, there is more incentive to pursue sound, non-politically influenced policies. ${ }^{309}$ In addition, Commissioners should be only removable for cause ${ }^{310}$ This type of agency structure is not uncommon in Brazil. For example, the National Water Agency's enabling statute allows at

${ }^{303}$ See id. at 435 .

${ }^{304}$ See id. at 478, 478 n.234 (citing numerous enabling statutes' requirement for Senatorial approval of appointments).

${ }^{305}$ See id. at 472. See generally Paul R. Verkuil, The Purposes and Limits of Independent Agencies, 1988 DuKE L.J. 257 (exploring the benefits of independent agencies that consist of Commissions or boards, not single decision-makers).

${ }^{306}$ See Constituição Federal [C.F.] [Constitution] arts. 45, 76-77 (Braz.); Senadoras e Senadores em Exercício, Ordenados por Partidos, SENADO FED., http://www.senado.gov.br/senadores/ senadoresPorPartido.asp [http://perma.cc/KUB6-TDAH] (stating that there are at least fifteen different parties represented in the Brazilian Senate today).

307 See, e.g., Lei No. 9.984, art. 11, de 17 de Julho de 2000, Diário Oficial DA UniÃo [D.O.U.] de 18.7.2000 (Braz.) (including a clause that prevents this type of conflict of interest in the National Water Agency's enabling statute, thereby barring industry members from taking part in the objective work that the agency does).

308 See, e.g., Lei No. 9.984, art. 9, de 17 de Julho de 2000, DiÁrio OFICIAL DA UNiÃo

[D.O.U.] de 18.7.2000 (Braz.).

${ }^{309}$ See Breger \& Edles, supra note 269 , at 1113.

${ }^{310}$ See Prado, supra note 295, at 435. 
will removal only for the first four months of a Director's term. ${ }^{311}$ After that, removal must be for cause. 312

Finally, the agency must be financially independent. If the President or Congress alone can withhold funding when unhappy with the agency's decisions or policies, then the agency is no longer insulated from political maneuvering. However, Brazilian agencies do often acquire some measure of financial autonomy when their enabling statutes stipulate that funding come predominantly from fees and fines collected by the agencies and that those fees be used only for their respective regulatory agendas. ${ }^{313}$ In practice, this may be difficult to achieve, as the President has authority over appropriations and budgets, even those derived from independent sources (i.e., the agency's own revenue). ${ }^{314}$ This hurdle cannot be defeated by any enabling statute and presents an ongoing struggle for the Brazilian regulatory state. ${ }^{315}$

\section{Authority to Ensure Animal Welfare}

Beyond its independent structure, the AWA must also have a purpose and significant authority to serve that purpose. As with the AWA in United States, the Brazilian AWA's mission should be to safeguard animals against cruelty from birth until death. The enabling statute must delegate significant authority to serve that purpose. Fortunately, unlike in the United States, there is an explicit constitutional mandate that the government protect animal welfare. ${ }^{316}$ The AWA must have the authority not only to enforce violations of the Constitution, but also to enforce all federal legislation and existing regulation that supports that constitutional mandate and involves the protection of animal welfare. ${ }^{317}$ Ultimately, all legal mechanisms that currently exist within Permanent Technical Commission on Animal Welfare and other agencies must be aggregated and consolidated into the AWA.

The benefit of a clear mission focusing solely on animals without regard to agricultural interests, economic interests, and transnational business interests, is that each phase of the animal's life can be governed by consistent standards. The AWA's independence and clarity of mission (i.e., pro-

${ }^{311}$ Lei No. 9.984, art. 10, de 17 de Julho de 2000, DiÁRIO OFICIAL DA UNIÃO [D.O.U.] de 18.7.2000 (Braz.).

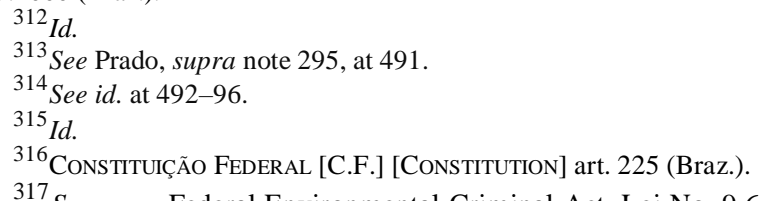

${ }^{317}$ See, e.g., Federal Environmental Criminal Act, Lei No. 9.605, art. 32, de 12 de Fevereiro de 1998, Diário Oficial DA União [D.O.U.] de 13.2.1998 (Braz.); Brazil Federal Decree on AntiCruelty No, 24,645, supra note 124; see also VAPNEK \& CHAPMAN, supra note 140, at 51 (describing regulations governing agricultural animal transport). 


\section{JURIS POIESIS}

REVISA DO CURSO DE DIREITO DA UNIVRSIDADE ESTACIO DE SA tection of animals from cruelty) would further ensure that existing legisla-tive and constitutional goals for prevention of animal cruelty were success-fully served. The agency's mandate would also provide a strong foundation from which to improve standards across the board.

\section{Benefits of an Independent Agency for Animal Welfare}

An agency whose mission is solely animal welfare could have an immediate and beneficial effect. The enabling statute would give it regulatory authority and a mandate to ease the lives of billions of animals whose current existence is nothing short of gruesome. ${ }^{318}$ What follows are just a few examples of how it might operate.

First, the AWA could review current farming practices to determine if the industry's chosen methods cause needless suffering. Under the current regulatory regime, necessity (when it is even considered) is determined with respect to the economic gains such methods produce. ${ }^{319}$ The AWA would prioritize the animal's experience.

Thus, for example, even if docking pigs' tails enables them to be penned in closer quarters, leading to more pigs per square foot and more profit, the AWA would consider the impact of this procedure on the pig and analyze whether it is necessary to the functioning of the industry. ${ }^{320}$ Among the things the agency might consider would be the current mortality rate at industrial facilities, the mortality rate if the animals were given more space, scientific data regarding the natural habits of the animals, and, of course, whether docking tails causes the pigs to suffer. ${ }^{321}$ The conclusion would almost certainly be that the animals require more space and that taildocking causes needless suffering. ${ }^{322}$

Second, the AWA could enable improved prosecutorial capability and encourage public involvement. This new agency could welcome evidence

${ }^{318}$ See supra notes 179-212 and accompanying text (discussing the cruel treatment of agricultural animals in the United States and Brazil).

${ }^{319}$ See Wolfson, supra note 2, at 151. See generally SCHAFFER ET AL., supra note 246, at 31, 33 (suggesting that considerations regarding necessity are viewed from an economic perspective).

${ }^{320}$ See COMPASSION IN World FARMing TR., THE TAIL-DOCKING OF Piglets 1 (1999), https://www.ciwf.org.uk/includes/documents/cm_docs/2008/t/tail_docking_of_piglets_1999.pdf [http://perma.cc/J9L5-M5P5]; Marc Bracke et al., Attitudes of Dutch Pig Farmers Towards Tail Biting and Tail Docking, 26 J. Agric. \& EnvTL. ETHICs 847, 855 (2013); Mhairi A. Sutherland, Welfare Implications of Invasive Piglet Husbandry Procedures, Methods of Alleviation and Alternatives: A Review, 63 N.Z. VETERINARY J. 52, 52-57 (2014).

${ }^{321}$ See COMPASSION IN WORLD FARMING TR., supra note 320, at 1; Bracke et al., supra note 320, at 855; Sutherland, supra note 320, at 52-57.

${ }^{322}$ See COMPASSION IN WORLD FARMING TR., supra note 320, at 1; Bracke et al., supra note 320, at 855 ; Sutherland, supra note 320 , at 52-57. 
of animal welfare violations from animal advocates and encourage individuals to provide evidence to law enforcement. ${ }^{323}$ Currently, in both the United States and Brazil, the prosecutor is often overburdened with other cases and sometimes politically tied to the interest of the industry, and, thus, enforcement seldom occurs. ${ }^{324}$ A federal agency dedicated to the protection of animal welfare would entrench norms that could then permeate into the fed-eral, state, and local regimes.

Third, because the AWA-rather than the entire agricultural industry - will regulate agricultural animal welfare, the agency can play a key role in providing expertise, investigation, and information that would more objectively design or contribute to the industry's operation in a way that protects animals from mistreatment. This is similar to the impacts of other federal statutes and agencies. For example, the Energy Policy and Conservation Act regulates mileage standards for the auto industry, forcing techno-logical upgrades as well as impacting manufacturing choices. ${ }^{325}$ With respect to the AWA, the statute could give the agency authority to influence industry choices through tax credits for purchases of equipment that pro-mote humane treatment. 326

The foregoing offer just a few of the many ways that the AWA could improve agricultural animal welfare-as well as animal welfare as it pertains to all animals - in two of the world's largest economies, the United States and Brazil. If either or both countries were to create such agencies, and new and effective welfare standards were to result, that would combine with the European Union's existing regulations to reduce the suffering quotient of billions of the world's animals.

\section{CONCLUSION}

The foregoing analysis demonstrates that while each country has a different statutory and regulatory regime, both countries arrive at a similar re-

${ }^{323}$ See Leahy, supra note 45 , at 63 . Even though lawsuits are not always successful, courts have allowed the "common" practice exemptions to be overcome when egregious conduct can be shown. Id. Therefore, advocates should not be discouraged by the blanket exemptions. Id.

${ }^{324}$ See Nicholas S. Bryner, Brazil's Green Court: Environmental Law in the Superior Tribunal de Justiça (High Court of Brazil), 29 PACE EnvTL. L. Rev. 470, 524 (2012); Roger W. Findley, Sustainable Development in Latin American Rainforests and the Role of Law, 32 TEX. INT'L L.J. 1, 4-5 (1997); Wolfson, supra note 2, at 147.

${ }^{325}$ Energy Independence and Security Act, 42 U.S.C. $\$ \$ 17001-17386$ (2012); Energy Policy and Conservation Act, 42 U.S.C. § 6201; see Bill Vlasic, U.S. Sets Higher Fuel Efficiency Standards, N.Y. Times (Aug. 28, 2012), http://www.nytimes.com/2012/08/29/business/energyenvironment/ obama-unveils-tighter-fuel-efficiency-standards.html?_r=0.

${ }^{326}$ See Eden Gray, Changing the Tax System to Effect Humane Treatment of Farm Animals, $3 \mathrm{~J}$. ANIMAL L. 159, 170 (2007). 


\section{JURIS POIESIS

sult: widespread mistreatment of agricultural animals. The United States lacks statutes that adequately address animal welfare. The few laws that do address animal treatment are plagued with exemptions, are not regulated and enforced, or are more concerned with the animal once it is dead. Brazil, on the other hand, has several statutes prohibiting cruelty towards animals and, more importantly, a constitutional provision that explicitly recognizes fundamental rights for animals. ${ }^{327}$ Yet despite these protections, Brazilian agricultural animals continue to suffer due to inadequate enforcement and widespread mistreatment.

The process toward a more humane agricultural animal treatment regime requires two steps. First, a statutory regime must be in place that defines and outlines the scope of animal welfare and the protections owed to animals. Second, there must be an effective method to implement the legal protections provided in step one. The United States is at step one; the government has yet to develop and enact legislation or regulations that sufficiently protect agricultural animals. Brazil has significant work to do for step one; European Union standards are present in Brazil, but are voluntary while statutes prohibiting animal cruelty are rarely prosecuted. Brazil is also struggling with step two, as it lacks an effective way to enforce the statutory and constitutional legal protections already in place.

An agency whose principal mission is animal welfare enables the necessary regulations to overcome step one and also dissolve the obstacles that plague step two. We have no illusions that the "solution" offered herein is simple, easy, or final. However, it does provide a step in the right direction, a step toward recognition that animal lives matter-whether they be pets or livestock. It would further require ongoing scrutiny of industry practices with the lives and well-being on the animals at the forefront of the analysis.

Of course, this agency will not eliminate cruelty. It would rather mark the beginning of a long overdue domestic and international conversation about the importance of animal welfare. That conversation would perhaps mark the beginning of an equally overdue conversation about the nature of our relationship with the nonhuman world. We look forward to both. As T.S. Eliot once said, "HURRY UP PLEASE IT'S TIME."328 
${ }^{327}$ See Constituição Federal [C.F.] [Constitution] 1988, art. 225 (Braz.).

${ }^{328}$ T.S. Eliot, The WASTE LAND 23 (Boni \& Liveright 1922). 
